\title{
Religião e Cultura Pop
}

\section{A vida em (um) vão: a busca de Deus em A obscena Senhora D., de Hilda Hilst}

Felipe Magalhães Francisco*

\begin{abstract}
"a vida foi isso de sentir o corpo, contorno, vísceras, respirar, ver, mas nunca compreender. porrisso é que me recusava muitas vezes. queria o fio lá de cima, o tenso que o OUTRO segura, o OUTRO, entendes? que OUTRO mamma mia? DEUS DEUS, então tu ainda não compreendes?”.
\end{abstract}

(A Obscena Senhora D., p. 53)

\section{Introdução}

A sensibilidade religiosa está aí, é porosa. A sociedade ocidental, em constante transformação, não fechou as portas para o religioso, apesar de um paradigma medievalpara a vivência da Religião, de Cristandade, não ser mais possível em nossos dias. A modernidade veio com uma promessa, entre outras, de que o ser humano, por vias da razão, alcançaria a estatura necessária que lhe fizesse caminhar por si próprio: o fim da Religião, nesse cenário, desenhava-se. De fato, o ser humano moderno, alcançou a autonomia e, de alguma forma, buscou sair da tutela das instituições, entre as quais, as religiosas.

Contudo, o ser humano é deveras complexo. A razão não trouxe aquela estatura esperada. Aquele vazio permanente, que nos faz seres da falta, segundo a inspiração freudiana, permanece; não foi saciado. A sede pelo infinito continua latente e, agora, mais autônomos e conscientes de nós próprios, continuamos à deriva, à procura por um sentido que

\footnotetext{
* Doutorando em Ciências da Religião, pelo Programa de Pós-Graduação da PUC-MG. Mestre e Bacharel em Teologia, pela Faculdade Jesuíta de Filosofia e Teologia.
} 
nos impeça do afogamento. É nesse lugar que a sensibilidade religiosa vem à tona, agora transformada e em construção por esse sujeito mais senhor de si.

A Literatura, tão sabedora do humano, tem a dizero quê, para nos ajudar a pensar a este respeito? Volvendo nosso olhar para o texto A obscena Senhora D., de Hilda Hilst, propomo-nos a refletir sobre essa questão, a partir da interface entre Literatura e Estudos de Religião, na esteira da busca por uma possível compreensão do sujeito hodierno e sua sensibilidade religiosa. Trata-se, pois, de refletir a respeito da tentativa humana para que a vida não seja em vão, aliada à busca por Deus, possível resposta para a sede do infinito.

\section{A obscena busca}

Hilda Hilst é uma das escritoras mais importantes da literatura contemporânea nacional. Sua obra, de uma qualidade e profundidade impressionantes, está a ser descoberta, tanto por leitores quanto por pesquisadores. Nascida em 21 de abril de 1930, dedicou-se por longos anos à criação literária, retirada à sua Casa do Sol, em Campinas, até que em 04 de fevereiro de 2004, aos 74 anos, veio a falecer. Para os pesquisadores e pesquisadoras de sua obra, uma tarefa muito difícil se impõe: evitar, o que deveras é bastante complicado, uma leitura psicologizante de seus textos. Há consonâncias irrenunciáveis entre a biografia da autora e as personagens que compõem a sua obra, levando-nos a uma identificação, quase que imediata, entre autora e obra.

O texto sobre o qual nos propomos a debruçar não foge a isso. Contudo, interessa-nos o texto literário, pois é a partir dele que queremos interpretar a sensibilidade religiosa do ser humano hodierno, nesse diálogo entre Estudos de Religião e Literatura. Lançado em 1982, o livro A obscena Senhora D. foi republicado em 2001, pela Editora Globo, numa organização editorial feita por Alcir Pécora, professor de teoria literária da Unicamp, e importante pesquisador da obra hilstiana ${ }^{1}$.

O livro, que exige leitura atenta, aborda, geralmente em primeira pessoa, o dramaexistencial de Hillé, uma senhora de sessenta anos, também chamada por seu marido, Ehud, de Senhora D. A partir do que é conhecido como fluxo de consciência, Hilda Hilst trabalha sua personagem, numa complexa teia de pensamentos e falas, intercalando os discursos e pensamentos da personagem principal, com os de seu falecido marido, bem como de seu pai, um homem tomado pela loucura, também falecido. No texto, também aparecem

\footnotetext{
${ }^{1}$ Esta é a edição da qual dispomos e que, doravante, citaremos apenas fazendo referência à paginação.
} 
diálogos de interlocutores da mesma vila em que vive Hillé, ora diálogos com a própria personagem principal, ora dos interlocutores entre si, a despeito da própria personagem.

O drama existencial de Hillé, que se desdobra no corpo, trata-se de uma busca para que a sua vida não seja em vão: Hillé tem o desejo de conhecer. Desejo, esse, intenso, inquietante e angustiante: "Vi-me afastada do centro de alguma coisa que não sei dar nome [...]” (p. 17). E por estar afastada desse centro, é que Hillé, um “eu à procura da luz numa cegueira silenciosa, sessenta anos à procura do sentido das coisas [...]” (p. 17), foi chamada por Ehud de Senhora D.: de derrelição.

O jogo com o apelido da personagem, atribuído a ela por seu marido, antes que esse falecesse, torna-se claro quando descobrimos que Hillé, aos sessenta anos, decide ir viver no vão da escada de sua casa. É uma atitude ascética, que faz com que a Senhora D abandone tudo, para viver sob as escadas: "Sessenta anos. Ela, Hillé, revisita, repasseia suas perguntas, seu corpo. O corpo dos outros [...]” (p. 43). Fugindo do que pode ser uma distração, a Senhora $\mathrm{D}$, numa ascese que, aqui, chamamos de platônica, quer dedicar-se à sua busca, às "obsessões metafísicas" a respeito das quais ninguém se interessa, a não ser ela, tomada por louca (cf. p. 26).

Enquanto todos os seus interlocutores tentam a trazer para o corriqueiro, lugar onde se desdobra o vemos ver da vida - com exceção de seu pai, tomado pela loucura -, a Senhora D. quer viver o peso das coisas: está interessada no porquê daquelas questões fundamentais que, vez ou outra, todos os que tomam consciência da vida se perguntam. E é nessa tensão que se desdobram todos diálogos travados na trama.Hillé, a desamparada, tende para o profundo e os seus interlocutores, incomodados sobremaneira com essa busca, querem a fazer emergir para o raso, para a superfície do corpo-pele. O desamparo é incômodo e, por isso, os interlocutores de Hillé a querem salvar:

\begin{abstract}
escute, Senhora D, se ao invés desses tratos com o divino, desses luxos do pensamento, tu me fizesses um café, hen? E apalpava, escorria os dedos na minha anca, nas coxas, encostava a boca nos pelos, no meu mais fundo, dura boca de Ehud, fina úmida e aberta se me tocava, eu dizia olhe espere, queria tanto te falar, não, não faz agora, Ehud, por favor, queria te falar, te falar da morte de Ivan Ilitch, da solidão desse homem, desses nadas do dia a dia que vão consumindo a melhor parte de nós, queria te falar do fardo quando envelhecemos, do desaparecimento, dessa coisa que não existe mas é crua, é viva, o Tempo" (p. 18).
\end{abstract}

O abandono pelo qual passa a Senhora D. é também abandono do seu próprio corpo: não é momento para que seja tocado, para a fruição do gozo. Ela repasseia seu corpo e o corpo dos outros, olhando para o além, para aquilo que na carne passa despercebido pelos 
desatentos, pelos que se prendem à fruição. $\mathrm{O}$ corpo é esse incompreensível, uma armadilha (cf. p. 21): o corpo é obsceno, não pela nudez, pelo desejo erótico que o toca, mas por aquilo que ele escancara e que se teima em não perceber; afinal, “o que é o corpo?”, pergunta Hillé (p. 38). Para Ehud, a solução do drama vivido pela Senhora D. está no corpo, tal como o senso comum, corriqueiramente, faz ecoar no dia a dia, que a maior parte dos problemas humanos significa falta de sexo, tal como se pode ver no extrato a seguir:

olhe, esse teu fechado tem muito a ver com o corpo, as pessoas precisam foder, ouviu Hillé? te amo, ouviu? antes de você escolher esse maldito vão da escada, nós fodíamos, não fodíamos Senhora $\mathrm{D}$ ?

$\operatorname{sim}$

e você gostava. me lembro das noites que você fazia o café, depois o roupão branco, teus peitos apareciam, eles não caíram os teus peitos, o que é que você faz, hen? escute Senhora D, estou descendo a escada, bem devagar, está ouvindo os meus passos?

$\operatorname{sim}$

então estou descendo, escuta, também posso foder nesse ridículo vão de escada não venha, Ehud, posso fazer o café, o roupão branco está aqui, os peitos não caíram, é assustador né, mas não venha, Ehud, não posso dispor do que não conheço, não sei o que é corpo mãos boca sexo, não sei nada de você Ehud a não ser isso de estar sentadoagora no degrau da escada, isso de me dizer palavras, nunca soube nada, é isso nunca soube

você se deitava comigo, mesmo não sabendo

$\operatorname{sim}$

perguntando sempre mas deitava.

$\operatorname{sim}$

quer dizer que nunca mais a gente vai meter?

não sei (pp. 22-23).

Hillé, a desamparada, vai habitar o vão da escada para poder revisitar o seu corpo, o corpo dos outros. É no corpo o lugar de onde nascem as perguntas de Hillé. Mas é preciso não desviar o olhar daquilo que realmente importa: na fruição do desejo erótico, no imediato dessa fruição, perde-se aquilo se deve buscar. Interessante perceber como, no diálogo supracitado, Hillé diz, perguntando, como pode dispor daquilo que não se conhece, que é o corpo. O corpo é mediação: é por ele que existimos, é por ele que nos relacionamos, é por ele que exercitamos nossa liberdade. Olhando para o corpo de Ehud, ainda assim, Hillé não é capaz de o conhecer.

Essa questão se torna ainda mais aguda, quando faz despertar o interesse pelo corpo de Deus. Começa, logo no início da narrativa, quando Hillé traz à tona a experiência da manducação eucarística, tal como podemos ver: 
Engolia o Corpo de Deus a cada mês, não como quem engole ervilhas ou roscas ou sabres, engolia o Corpo de Deus como quem sabe que engole o Mais, o Todo, o Incomensurável, por não acreditar na finitude me perdia no absoluto infinito (p. 19).

Um corpo não é só um corpo. O corpo é obsceno justamente por isso: ele pode revelar mais que o imediato do toque, da pele, da pulsão. É nessa perspectiva que Hillé aponta para o Corpo de Deus. Note-se que o jogo da palavra não faz menção ao Corpo de Cristo, tal como os cristãos e cristãs usualmente afirmam sobre a eucaristia, mas ao Corpo de Deus. Que Deus é esse? É o absolutamente Outro, Infinito, Imensurável. O Mais! La obscura cara (cf. p. 66). Interessante perceber o uso repetido do verbo "engolir". Não se trata de uma refeição eucarística, na qual se saboreia uma intimidade com o Senhor, tal como aspiram os cristãos e cristãs. Trata-se da fome: Hillé engole na ânsia de quem tem fome. Fome de quê? “[...] salivosa lambendo e pedia: que eu possa compreender, só isso [...]” (p. 20). Deixou de engolir o Corpo de Deus, porque não podia compreender.

A única referência feita a Cristo, no texto, refere-se à pergunta sobre a sua humanidade (cf. p. 67). Curiosamente, também faz uso do verbo engolir, mas, aqui, já não em contexto eucarístico. Denota, ao que parece, um sentido mais antropofágico. Questionando sobre se, de fato, Cristo fosse um homem, Hillé levanta a pergunta sobre o saber que ele deveria ter a respeito do grande desconhecido: estar no mundo "sabendo que há um pai eternamente ausente" (p. 67). Ora, se Cristo só pode ser considerado humano se partilhar da ausência eterna do Outro, logo, o que define a humanidade é a permanente ausência de Deus. É por isso que Hillé grita: “[...] não há um vínculo entre ELE e nós? não dizem que é PAI? não fez um acordo conosco? fez, fez, é PAI, somos filhos. não é o PAI obrigado a cuidar da sua prole, a zelar ainda que a contragosto? é PAI relapso?" (p. 38).

O Deus que desponta no texto é o absolutamente transcendente. É sagrado na radicalidade do termo: separado. É “Aquele [que] nada tem a ver com isso" (p. 20), com isso a que se refere ao mundo humano, à contingência. É o Deus Ausente. Descortina-se, para nós, aqui, a ambivalência do nome-apelido Derrelição, desamparo, abandono: é desamparo e abandono não só porque Hillé foi viver sob o vão da escada, mas porque sua existência é um estado de desamparo e abandono por parte do Infinito, o Deus Ausente.

Chegamos, nesse sentido, ao âmago daquilo que acreditamos tratar-se de uma possível religiosidade presente na literatura de Hilda Hilst, tal como desponta no texto, objeto de nossa análise: na relação com Deus, o aceno não está no encontro, mas na busca por ele:

olha, Hillé a face de Deus

ondeonde?

olha o abismo e vê 
eu vejo nada

debruça-te mais agora

só névoa e fundura

é isso. adora-O. Condensa névoa e fundura e constrói uma cara. Res facta, aquietate. (p. 47).

Essa ausência é o abismo. Metáfora, aliás, muito comum para dizer da separação entre o divino e o humano. Olhando para ele, a Senhora D. vê o nada, névoa e fundura. Lembra, um pouco, traços de narrativas teofânicas. Hillé é convidada a adorar o Ausente, o opaco. Mais que isso, é convidada a aquietar-se. Res facta!

Associada à imagem do abismo está a do reino dos mortos. O modo como Hilda Hilst trabalha a habitação dos mortos, em $A$ obscena Senhora $D$, faz eco à primeira imagem bíblica da mansão dos mortos, o Sheol bíblico, que tem seu correlato por Hades, na mitologia grega, e Infernum, para os latinos. Trata-se de uma ambiência na qual se vive sem vitalidade. A curiosidade que brota em Hillé, a respeito do reino dos mortos, ultrapassa o que chamaríamos, aqui, de fantasias de céu. O que a Senhora D. continua a buscar é o Outro. Se ele está distante do "lixo" que criou (cf. p. 37), seria possível que estivesse junto ao asqueroso?

\begin{abstract}
como é o Tempo, Ehud, no buraco onde te encontras morto? como vive o Tempo aí? Escuro, e derrepente centelhas de cores, como é o Tempo do inchado, do verme, do asqueroso?O que é asqueroso? Como é o Tempo no úmido do fosso? Pergunto ao Menino Louco: estás aí com Ehud? Morte, asqueroso, inchado, vermes, fosso fazem parte de Ti? (p. 39).
\end{abstract}

Ainda a respeito do asqueroso do que é o morrer, Hillé se interessa também sobre a relação entre Deus e o cadáver, tal como podemos ver no extrato a seguir:

Ele está em ti, Ehud, agora que estás morto? como é o Menino Precioso dentro de Ehud morto? fervilha, tem muitas cores, pulula, Corpo de Deus em Ehud morto é difícil de ser visto pelo olho do vivo, cobrimos nosso rosto, volteamos, procuramos para nossas narinas um tecido grosso, Ehud tuas unhas limpíssimas escovadas a cada dia, tua lisa mucosa, o ventre que cuidavas, as omoplatas retas, os pés de Ehud, longos, sóbrias as curvas das arcadas, os pequenos espaços do teu corpo de carne são do Todopoderoso agora propriedades, como estão, Ehud, teus pequenos espaços de carne? E teu esôfago, tua língua, e os pelos das tuas sobrancelhas eriçadas, e as pálpebras pálidas, e as mãos e as palmas? E o sexo, Ehud? [...] O que é o corpo? (pp. 37-38).

A intuição de Hillé, que a faz questionar a presença do Ausente em meio ao asqueroso, é um ponto deveras importante no tema da busca por Deus. Já ao fim da narrativa, algo inesperado se dá: uma porca invade a casa da Senhora D. Hillé passa a chamar a porca de 
senhora P. Na porca, há uma ferida, um roxo-encarnado, que é cuidado por Hillé: "Hoje pude me aproximar muito lenta, e como diria o sóbrio: pensei-lhe os ferimentos" (p. 87). Do toque na ferida, a lembrança da própria ferida, do próprio vazio da ausência de Deus. O toque, que diríamos místico, faz irromper uma oração:

\begin{abstract}
Porque não me tocaste, Senhor, e nem me pensaste sóbrio os ferimentos, porque nem o calor da ponta dos teus dedos foi sentido por mim, porque mergulho num grosso emaranhado de solidões e misérias e te buscando emerjo de mim mesma as mãos cheias de lodo e de poeira, este meu roxo-encarnado sem vivez reside em mim há séculos, lapidescente na superfície mas fervilhante e rubro logo abaixo, eterno em dor com a tua esquivez. Rimas pesadas ciciosas, sem intenção, e os unguentos no lombo da senhora $\mathrm{P}$, roçados de focinho, fungadas mornas no meu braço, os olhos um aquoso de incompreensão e de doçura, um sem-Deus sem-Deus hifenizado sempre, sem-Deus sem-Deus. Conheces o canto do pássaro sem-fim, senhora P? sem-fim, sem-fim, sem-fim nosso existir sem-Deus. E me vem que só posso entender a senhora $\mathrm{P}$, sendo-a. Me vem também, Senhor, que de um certo modo, não sei como, me vem que muito desejas ser Hillé, um atormentado ser humano. E SENTIR. Ainda que seja o aguilhão de um roxo-encarnado aparentemente sem vivez (pp. 87-88).
\end{abstract}

\title{
A ausência como conclusão
}

Sem-Deus. Sem-Deus. É assim que Hillé, a desamparada, concebe sua vida. A ausência do Menino-Porco não lhe tira, porém, a sede da busca. E é justamente na busca o aceno para o profundo. A vida não é em vão, não porque encontra, mas porque busca. Há um contraste claro entre a conformação dos interlocutores de Hillé, e a ânsia pelo Mais, de nossa personagem. A ela não basta o comum. E é por isso que ela pode romper, com agressiva assertividade, com o representante legítimo da religião, o Padre, quando este se apresenta como "um homem como outro qualquer" (p. 32). De que vale a confissão e a comunhão, se elas não trazem as respostas? Continua-se a perguntar, apenas.

O cenário da permanente busca pelo Ausente parece corresponder ao que temos vivido, em nosso tempo. Deus não é uma certeza, não mais. Não é à-toa que, cada vez mais, as pessoas costumam se dizer agnósticas. A sensibilidade para o Sagrado está aí. O Deus cristão, a partir do qual a cultura ocidental foi construída, não é mais onipresente. O Sagrado é multifacetado, numa presença-ausência. O campo para as religiões está aberto, para que ofereçam palavras responsáveis, que encontrem o coração daqueles que buscam o Ausente, nesses nossos tempos de desamparo. 


\title{
Utopia e religião: as percepções culturais pós-modernas acerca da esperança pós-morte em Black Mirror
}

\author{
Utopia and religion: \\ postmodern cultural perceptions of postmortem hope in Black Mirror
}

Karen de Souza Colares²
karencolares5@gmail.com

Resumo: A pós-modernidade possui como linguagem primordial o mundo imagético. $\mathrm{O}$ advento das mídias de tela veio para consolidar a ruptura das lógicas da modernidade e instaurar um modo completamente novo de elaborar discursos. Os serviços de streaming são parte desta composição e se colocam cada vez mais como porta-vozes das percepções culturais predominantes. Em um movimento de retroalimentação, as noções culturais não apenas se moldam a partir destes meios de comunicação em massa, mas também influenciam a produção que se atesta neles. Despontando como ícone de uma geração, a série Black Mirror aborda os conflitos próprios de uma cultura tecnológica. Com especial atenção ao episódio San Junipero, este artigo tenciona esclarecer as noções religiosas presentes nesta obra cinematográfica e de que maneira seu discurso representa os anseios de uma geração. Espera-se perceber nesta análise em que medida o discurso religioso acerca da vida após a morte ainda possui lugar de fala na cultura ampla e que características assume na sociedade líquida.

Palavras-chave: Utopia; esperança pós-morte; Black Mirror; religiosidade.

Abstract: Postmodernity has as its primordial language the imaginary world. The advent of the screen media came to consolidate the rupture of the logics of modernity and establish a completely new way of elaborating speeches. Streaming services are part of this composition and are becoming more and more as spokespersons for prevailing cultural perceptions. In a feedback movement, cultural notions not only shape themselves from these mass media but also influence the production that is attested to in them. Emerging as an icon of a generation, the Black Mirror series addresses the conflicts inherent in a technological culture. With special attention to the San Junipero episode, this article intends to clarify the religious notions present in this cinematographic work and in what way its discourse represents the yearnings of a generation. In this analysis we hope to realize the extent to which the religious discourse about life after death still has a place of speech in the broad culture and what characteristics it assumes in the liquid society.

Keywords: Utopia; postmortem hope; Black Mirror; religiosity.

\section{Cultura pós-moderna}

A cultura é uma grande teia de sentidos. Não existe qualquer possibilidade de que os seres humanos possam se esquivar dessa construção. Em todo tempo, através de sua ação no

\footnotetext{
${ }^{2}$ Mestranda em Teologia na Faculdade Jesuíta de Filosofia e Teologia. Bolsista CAPES.
} 
mundo, estão montando e desmontando sentidos. Na atualidade, tempo que se convencionou chamar pós-modernidade, a explosão de instrumentos de comunicação em massa trouxe significativa alteração na maneira como estes sentidos são então projetados pela e na cultura. As mídias de tela: cinema, internet e TV multiplicam narrativas de gêneros variados, mas sempre deixando entrever um pouco do submundo a alimentar o fenômeno cultural. Dentro deste amplo arcabouço de gêneros, o ficcional sempre gosou da fama de ser instrumento pouco confiável para o conhecimento das realidades humanas. Estaria este sempre a mentir?

\begin{abstract}
Quando lemos romances, não somos o que somos habitualmente, mas também os seres criados para os quais o romancista nos transporta. Esse traslado é uma metamorfose: o reduto asfixiante que é nossa vida real abre-se e saímos para ser outros, para viver vicariamente experiências que a ficção transforma como nossas. Sonho lúcido e fantasia encarnada, a ficção nos completa - a nós seres mutilados, a quem foi imposta a atroz dicotomia de ter uma única vida, e os apetites e as fantasias de desejar outras mil. Esse espaço entre a vida real e os desejos e as fantasias, que exigem que seja mais rica e mais diversa, é preenchido pelos livros de ficção. (LLOSA, 2004, p. 21.)
\end{abstract}

Ao contrário do que se pensa sobre o caráter falacioso das obras ficcionais, estas se encarregam de deixar transparecer a verdade de que os homens e mulheres estão em um movimento contínuo de insatisfação. Tais produções surgem como meio possível para se alcançar o destino almejado, se tornando assim meio de esperança, a concretização mais aproximada a que se pode chegar. Mas quais configurações assumem as ficções de um tempo em que as grandes narrativas estão mortas? Quando os discursos, palavras e metanarrativas perdem sua força, como se articulam os discursos de esperança?

A atualidade encarna tal descrédito com relação à religião. A moldura discursiva religiosa que antes se constituía em matriz predominante para a reflexão sobre esperanças de vida e morte foi lentamente substituída por percepções utópicas cujas características recorrentes: declínio da religião na formação e condução da sociedade; a noção de evolução humana e a perspectiva de que está em direção a algo superior; relevância da temática econômica para implementar o bem social almejado antes deixado a cargo de um ente externo e a exaltação da tríade: tecnologia, ciência e maquinaria (WALSH apud KOPP, 2011, p. 44) cuidaram de enuviar as máximas até então elevadas. De acordo com Walsh, as utopias esmoreceram século XX à dentro, dado o fato de que se mostraram de certo modo paradoxais. Nem tudo o que se imaginou ser um progresso, se concretizou como tal, assim, elas tiveram sucessos e fracassos. 
Através das obras ficcionais, podemos contemplar as pulsões que insistem em perpassar à expectativa humana. A conexão do espectador com um artifício narrativo tão caracterizado pela descontinuidade em relação à sua própria realidade flui livremente em virtude dessa identificação. As produções que se circunscrevem no amplo bojo ficcional não se ocupam em retratar a experiência humana, mas de acrescentar-lhe um elemento ausente. A angústia hodierna está agora ligada à inevitabilidade de sociedades antes concebidas como utópicas. Aqui tem lugar o termo distópico. A reflexão recai então sobre os perigos advindos de sociedades que se imaginem como utopias. O que antes pareciam presságios de tempos dourados, surgem no horizonte como iminentes ameaças. Fazendo jus às características de seu tempo, as mídias de tela se povoam de produtos permeados destas intuições.

\section{Definições metodológicas}

Para fazer emergir algumas das intuições da presente cultura acerca da esperança religiosa no que se refere à vida pós-morte, este artigo privilegiará um dos muitos instrumentos das mídias de tela: os serviços de streaming, serviços que disponibilizam na privacidade do lar, as mais recentes produções cinematográficas, uma mistura de TV e cinema. Para que a análise seja pertinente, se fará necessária a delimitação ainda mais especifica de uma série e episódio. A série pinçada aqui deve sua escolha à propriedade com a qual ilustra os conflitos de uma geração cada vez mais pautada pelos avanços tecnológicos. Black Mirror ${ }^{3}$, como definida pelo site do serviço que a veicula, é uma antologia de ficção científica na qual são abordados os possíveis dilemas a serem encontrados na dinâmica de um futuro não tão distante, sociedades utópicas e distópicas são o pano de fundo dos episódios que a compõem.

A despeito de seu caráter cinematográfico, a ficção também é uma narrativa, sendo possível a cooptação de métodos de interpretação textuais de forma adaptada para a 'leitura' da película. $\mathrm{Na}$ interpretação de uma narrativa pelo menos dois aspectos precisam ser explorados, o poético que estuda a dimensão artística ou o modo como a trama é construída pelo autor e 'o quê', que faz emergir a mensagem que se deseja comunicar. Para análise destas facetas, tomar-se-á de empréstimo das ciências bíblicas a metodologia da crítica da narrativa. Este método surge no universo da pesquisa histórico-crítica do século XIX-XX

\footnotetext{
${ }^{3}$ Black Mirror é uma série de 4 temporadas disponibilizada no serviço de streaming denominado Netflix e ao qual se tem acesso mediante pagamento de mensalidade. Criada pelo crítico, humorista, roteirista e escritor Charlie Brooker.
} 
quando as escolas da crítica da fonte e da tradição não conseguiam fazer jus a todas as facetas de textos narrativos complexos como as Escrituras judaico-cristãs. (OSBORNE, 2009)

\section{Análise estrutural}

O primeiro tópico a ser explorado para que o sentido de uma narrativa se mostre de maneira mais clara é sua estrutura. A consideração de suas diferentes partes deverá contribuir para que o significado da narrativa em sua amplitude seja corretamente apreendido e as peculiaridades das perícopes não desviem o foco da mensagem que está sendo criada. Uma leitura fechada do próprio 'texto' em nível macro nos coloca diante da história de Yorkie e Kelly que se encontram naquilo que ficará mais claro posteriormente, se tratar de uma realidade virtual. Yorkie, tímida e vacilante se retrai diante das várias possibilidades que a festiva cidade de San Junipero podem oferecer, enquanto Kelly se porta de maneira completamente desinibida, se lançando às experiências que almeja no único intuito de diversão, sem as obrigações advindas dos laços emocionais. Compondo a narrativa maior do encontro destas personagens estão suas próprias tramas individuais. Fora da realidade virtual de San Junipero, Kelly está imobilizada em seu leito à muitos anos devido a um acidente de carro no qual se envolveu na noite em que decidiu confessar à sua família, religiosa tradicional, que era homossexual. Kelly, por sua vez, também idosa, luta sozinha contra o câncer, após a morte precoce de sua filha, dor que compartilhou com o marido com quem esteve em união por 49 anos. San Junipero, uma metáfora da eternidade, para a qual os indivíduos podem fazer upload de suas consciências para viverem após suas mortes, possui significado diferente para ambas as personagens, como ficará claro a seguir. As ênfases secundárias que se unem para criar a ênfase principal.

\section{Análise estilística}

O tópico a ser contemplado a seguir é o cenário geográfico ou histórico no qual é construída a narrativa. Como realidade virtual que é, existe grande maleabilidade para a composição do ambiente. Inicialmente, o encontro de Kelly e Yorkie se dá na década de 80 . Após envolvimento sexual, Kelly parece se esconder visitando diferentes décadas, o que justifica com o simples argumento de que 'gosta de variar a música', mas na verdade, se explica por sua percepção do apego que a recém-conhecida já lhe demonstra. Yorkie passa a procurar em cada nova década por aquela que se tornou o ápice de todas as experiências que não pôde efetivamente viver. A caracterização das personagens pode assumir marcação 
bastante delineada visto, que a busca se passa em diferentes décadas com suas roupas e músicas próprias. A despeito da descontinuidade própria da ficção, o anseio humano por uma vida bem vivida e a esperança de dias melhores estará muito presente nos diálogos e assim, a identificação com Kelly e Yorkie se torna tarefa fácil ao espectador. O tempo da narrativa e da história não se preocupa com a sucessão histórica tal qual, mas se trata muito mais de um arranjo literário. A descontinuidade temporal existente no fato de que a cidade só pode ser visitada uma vez por semana e sempre ambientada em um sábado, aumenta o envolvimento do espectador no drama. A lacuna de conhecimento sobre o que efetivamente se passa, mantém a expectativa do desenvolvimento. O leitor se sente mais conectado com as emoções da narrativa e passa também a esperar pela próxima oportunidade de prazer. Dentro da análise estilística, há que se empreender algo a que se pode denominar de análise exegética. Neste ponto, se atentará aos diversos mecanismos literários utilizados para aprofundar o enredo: repetições textuais, simbólicas e temáticas, pontos de vista esboçados, recortes editoriais, antíteses e ironias.

As repetições funcionam como um comentário implícito, o modo como o autor conta sua narrativa. E o que se repete em cada década que Yorkie visita na busca do encontro com Kelly é o seu anseio por aquilo que não pôde realizar em vida. Para ela, a eternidade é uma expectativa necessária diante da dramática existência vivida. Palavras-raiz e cognatos usados para causar este efeito são 'curtir', 'aproveitar', 'divertir' e 'dançar'. Aqui, como também em alguns textos bíblicos, como o Evangelho de João, as realidades humanas são elevadas à máxima potência para que se possa conceber uma realidade transcendente. ${ }^{4}$ Repete-se também uma imagem concreta usada simbolicamente, a da noite de sábado. É preciso atentar para a apresentação de pontos de vista diferentes mesmo dentro do ciclo de repetições. À medida que a temática chave da festa se repisa são intercaladas diferentes perspectivas acerca do sentido para se estar ali. Pontos de vista apontam para a força da narrativa. Para se compor os pontos de vista lançam-se mão da dimensão psicológica e valorativa. No que se refere ao aspecto psicológico, são fornecidas informações internas sobre os pensamentos e sentimentos dos personagens que de outra forma o espectador jamais poderia conhecer. Tem-se aqui uma espécie de 'narrador onisciente' ao qual nada escapa. Esse conhecimento vai sendo compartilhado e cuida de cooptar a cumplicidade daquele que testemunha a trama. $\mathrm{Na}$

\footnotetext{
${ }^{4}$ O Evangelho de João é amplamente reconhecido pelo uso de termos como "pão da vida", "água da vida" e "vida eterna". Nestes, elementos inicialmente triviais da existência são cooptados para a sugestão de uma qualidade de existência sem parâmetros exatos. A ineficácia da comunicação desta realidade reforça a característica sui generis de concepções que fujam à realidade intra-histórica. Para mais: BLANCHARD, YvesMarie. São João. São Paulo: Paulinas, 2007.
} 
dimensão valorativa ou ideológica, conceitos de certo e errado são traçados e permanecem na narrativa. Existe no episódio em questão um conflito essencial entre as personagens acerca do que significa não apenas a esperança da vida após a morte, mas também sobre o papel que a tecnologia no que se refere à esperança diante da existência puramente material. O julgamento do narrador e a maneira como as perspectivas expostas conflitam com a ênfase que ele deseja gerar, ficará mais evidente no recorte de material que ele faz. A princípio, o autor e narrador estão implícitos, saindo da penumbra apenas nas partes editoriais. O ponto crucial em que a perspectiva do narrador acerca da artificialidade da vida criada de maneira virtual ficará às claras será no abrupto recorte de cena que faz entre a alegria das duas personagens que resolvem fazem 'sua passagem' e então viverem eternamente em San Junipero e o robô, que mecanicamente realoca as muitas peças que compõem o software que viabiliza a experiência da 'eternidade'. Esta costura fornece transição para outro tipo de material apontando para uma ênfase temática específica. Este ponto evidenciará de maneira mais clara a mão do autor e o 'sobre o quê' deseja narrar. Aqui, a qualidade de vida que Yorkie consegue enxergar em uma realidade puramente virtual se constituirá em elemento irônico. Qual a virtude de algo que efetivamente não é real?

\section{Análise teológica}

Intrinsecamente conectada à maneira como um narrador compõe sua obra está aquilo que deseja comunicar. Ver, ler ou analisar uma ficção demanda uma exigência frente ao drama que se apresenta. Obviamente, esta apreensão dos conflitos e lições presentes na trama pode ser realizada a partir de infinitos pontos de partida e aqui, assumem-se as premissas do horizonte religioso cristão.

O teólogo Jurgen Moltmann asseverou tempos atrás que quando o Cristianismo se mostrou como uma fé em Deus sem um futuro para o mundo, logo, a cultura secular se encarregou de modelar um futuro sem a fé em Deus. A emergência das utopias, sociedades ideais que pudessem regenerar o caos social são uma atestação desta verdade. Um Deus sem futuro conduziu a um futuro sem Deus. (MOLTMANN, 1968, p. 370) Seria a fé religiosa item relativo somente ao passado?

Responder a essa questão demanda crítica da experiência de fé que se fez predominante na cultura ocidental. Evidentemente, o caráter multifacetado do fenômeno religioso resiste às generalizações. A despeito disso, o materialismo que se fará atestar no século XIX em diante não aparece no éter, mas conectado às noções religiosas vigentes. Parte 
de seu estabelecimento advém do esforço da construção da vida aqui e agora, sem a dependência de uma instância exterior, tendo já posto a morte de Deus. Uma religiosidade cada vez mais amedrontada diante das inovações em curso debruçou-se em muitos momentos sobre si mesma e perdeu a conexão vital com as angústias que agora marcavam o cenário. A tensão entre um Reino de Deus a ser implantado no futuro escatológico e as urgentes demandas sociais pendeu no seio religioso para diferentes ênfases discursivas, o que certamente redundou em muitos equívocos. A manutenção do caráter duplo da existência humana e assim, do reino divino, já e ainda não, é o modo de se cooptar os esforços do presente da fé para o futuro. Nesse diálogo de realidades, a esperança se torna força motriz das mudanças presentes e se esvai a necessidade de fazer calar o sentimento religioso para que se possa agir em função da humanidade. Se o ímpeto religioso se esvai das realizações da existência, que se dirá das expectativas pós-morte? Realmente não faz sentido algum manter noções de eternidade após a única vida na qual se tem fé. Viver é uma aposta única. Em viver bem a própria vida está o descanso daqueles que não imaginam nada além da matéria, mas o horror da existência trágica poderia fazer evocar a esperança de uma nova possibilidade. Nas palavras de Kelly, "viver bem é estar pronto para todo o resto." Assim, a expectativa de uma vida após a morte seria o recôndito daqueles que viveram de modo medíocre. A esperança seria fuga dos impotentes frente à realidade.

Os elementos aos quais atentamos agora estão presentes de modo abundante no episódio que é objeto de análise. Todas as repetições imagéticas e fraseológicas cuidaram de tecer cuidadosamente a agonia de uma geração que deseja conservar o máximo de sua existência finita. 'Só ter algumas horas ou meses' surge como um mote. Constatação acerca da fugacidade já presente no Livro bíblico de Eclesiastes: "Vaidade de vaidades, tudo é vaidade". A juventude encarnada pelas personagens no ambiente virtual de San Junipero denuncia o medo frente à decrepitude, medo engrandecido pela perspectiva materialista.

A relação afetiva aparece como a mais aproximada concepção de paraíso. Nesse quesito, uma existência eterna sem aqueles aos quais se amou é confinar-se em um ambiente no qual nada importa. Aversão apresentada acerca da eternidade se mostra como a fixação do gozo juvenil, sem compromissos, pois afinal, comprometer-se não é divertido. Nesse âmbito, sentir também não é diversão. O paraíso surge como alienação da realidade. É interessante notar que dentro da própria cidade de San Junipero existe um bar que poder-se-ia caracterizar como o inferno: masoquismo, sadismos, brigas e bebedices compõem o ambiente. Assim, os convencionais céu e inferno são uma opção virtual possível a todo ser humano e ao mesmo tempo. Aqui, a emergência das escolhas éticas feitas em vida simplesmente não possui 
qualquer foco. $\mathrm{O}$ importante, sobretudo, é viver bem e viver bem significa compreender a própria finitude. $\mathrm{O}$ medo humano frente à extinção completa elimina todos os demais temores e torna relativas muitas demandas aparentemente urgentes.

\section{Conclusões Parciais}

Atentar às produções de uma cultura é debruçar-se sobre sua mentalidade e anseios. Novas linguagens surgem para a comunicação do submundo da cultura, mas será que se pode dizer que são novas suas inquietações? As mídias de tela são o grande ícone da geração pósmoderna e inevitavelmente discursarão sobre o levante de conflitos próprios de uma cultura tecnológica. As afirmações aparentemente distantes dos discursos religiosos ainda revelam a pungente necessidade antropológica de um horizonte adiante. A fé na vida enquanto tal e na experiência pós-morte não precisam ser polarizadas. Perceber que a fé do futuro pode cooptar as ações do presente é uma maneira de fazer dialogar dois lados de uma única moeda: a existência. Assim, urge não apenas compreender as pulsantes inquietações de uma geração obcecada com a noção de efemeridade, mas propor-lhe reflexões acerca das complexidades envolvidas em um estilo de vida que não considera o dia de amanhã, seja este escatológico ou não.

\section{Referências Bibliográficas}

GRENZ, Stanley. Pós-modernismo. Um guia para entender a filosofia do nosso tempo. São Paulo: Vida Nova, 2008.

KOPP, Rudinei. Comunicação e mídia na literatura distópica de meados do século 20: Zamiatin, Huxley, Orwell, Vonnegut e Bradbury. Porto Alegre: PUC-RS, 2011. Tese de doutorado não publicada.

LLOSA, Mario Vargas. A verdade das mentiras. In: $A$ verdade das mentiras. São Paulo: Editora Arx, 2004. p. 15-30.

MOLTMANN, Jurgen. Hope and History.

OSBORNE, Grant R. Narrativa. In

A espiral hermenêutica. Uma nova abordagem à interpretação bíblica. São Paulo: Vida Nova, 2009. p.254-283. 


\title{
Esperança e cotidiano. "O Samba é uma forma de oração!"
}

\author{
Hope and everyday life. "Samba is a way of praying!"
}

\author{
Rosemary Fernandes da Costa ${ }^{5}$
} rosenandescosta@gmail.com

\begin{abstract}
Resumo: No enraizamento cotidiano do povo brasileiro, a esperança é mola propulsora de vida. Ela é um princípio mobilizador em torno do qual todas as coisas ganham novo olhar e novas possibilidades. Ele nos permite ter sonhos, fazer sacrifícios, criar projetos, e quando derrotados, nos reerguermos. Nosso povo, em seu chão violado e, ao mesmo tempo, incansavelmente fecundo, expressa em ritmos, versos, danças e indumentárias, suas narrativas de sentido. Nesta pequena reflexão apresentaremos a dimensão litúrgica e escatológica presente em alguns versos dos sambas de muitas épocas que expressam um enraizamento no cotidiano e, ao mesmo tempo, uma dinâmica relacional subjetiva e intersubjetiva, cultural e histórica, presente e meta-histórica.
\end{abstract}

Palavras-chave : esperança, sagrado, samba, escatologia, liturgia

Abstract: Hope is the driving force of life in the daily rooting of Brazilian people. It is a mobilizing principle around which all things gain a new point of view and new possibilities. It allows us to have dreams, make sacrifices, create projects, and, when defeated, standing back up. Our people, in their violated and, at the same time, tirelessly fecund soil, express in rhythms, verses, dances and costumes, their different narratives of meaning. In this small reflection, we will present the liturgical and eschatological dimension present in some verses of the sambas of many times that express a rooting in daily life; and, at the same time, a subjective and intersubjective relational dynamics, both cultural and historical, both present and metahistorical.

Keywords: hope, holy, samba, eschatology, liturgy

O tema da esperança parece estar na balança nesse momento histórico tão conturbado, no qual narrativas de sentido parecem não ter mais lugar nas perspectivas pessoais e comunitárias. Contudo, no enraizamento cotidiano do povo brasileiro, a esperança é mola propulsora de vida, como nos lembra o pensador Ernst Bloch. A esperança não é uma virtude entre outras, é um princípio mobilizador, um princípio ativo, um eixo referencial em torno do qual todas as coisas ganham novo olhar e novas possibilidades. Ela nos permite ter sonhos, fazer sacrifícios, criar projetos, e quando derrotados, nos reerguermos.

\footnotetext{
${ }^{5}$ Rosemary Fernandes da Costa é doutora em Teologia Sistemático-Pastoral pela PUC-Rio, especialista no tema da MISTAGOGIA. Professora da Cultura Religiosa na PUC-Rio e de Filosofia na Secretaria de Educação do Rio de Janeiro. Autora dos livros Mistagogia hoje (2014) e A Mistagogia em Cirilo de Jerusalém (2015), pela Paulus, SP.
} 
Nossa inspiração nesta pesquisa-reflexão tem um caminho pessoal que cito brevemente. Sou neta de amante de Noel Rosa - Djalma Fernandes -, que ouvia as canções compostas por Noel na boemia e, nos inesquecíveis cafés da manhã, partilhava comigo suas paixões musicais. Outro fator que determinou este percurso foi a eterna presença de uma amiga-irmã - Lucia Maria Martins -, que me conduzia cotidianamente pelos caminhos do samba, me ensinou a sabedoria que brotava da fonte do Jongo. Para cada situação da vida, ela tinha um verso-samba para me orientar. $\mathrm{O}$ terceiro grande elemento é a minha experiência com uma linda comunidade cristã, na qual somos cuidados-embalados por um sambista - José Augusto Simões -, nosso catequista, mistagogo, companheiro de todas as horas. Enfim, com esses profundos conteúdos que me habitam e a convivência nas quadras, rodas de jongo e de samba, resgato o verso de Vinícius de Moraes, em Samba da Bênção, como inspirador deste projeto muito precioso e humilde:

É melhor ser alegre que ser triste, Alegria é a melhor coisa que existe: é assim como a luz no coração Mas pra fazer um samba com beleza é preciso um bocado de tristeza É preciso um bocado de tristeza senão, não se faz um samba não Fazer samba não é contar piada e quem faz samba assim não é de nada O bom samba é uma forma de oração Porque o samba é a tristeza que balança e a tristeza tem sempre uma esperança A tristeza tem sempre uma esperança de um dia não ser mais triste não

Tematizar a esperança é abrir possibilidades, pois nos conduz a uma dinâmica relacional, à revisão de questões fundamentais sobre o sentido da vida, o que dá sentido ao nosso cotidiano e para onde nos orientamos. Relembramos Albert Camus, quando inicia sua primeira obra trazendo exatamente esta como a questão ontológica fundamental - julgar se a vida merece ou não ser vivida - que, se não respondida, conduz a ausência de sentido da vida, portanto, ao suicídio. (Camus, s/d, p. 13)

A reflexão do filósofo nos diz que não estamos diante de um tema a ser tratado em contexto derradeiro, como final dos tempos ou apocalíptico, mas diante de um convite para observarmos a perspectiva vital que nos move e que move a história. Com Ernst Bloch como guia, visitamos o conceito de utopia como uma articulação entre estética, ética e filosofia da história. Essa mesma estrutura inspiradora e convocadora de utopias é o que podemos perceber na elaboração de um povo que bebe nos ritmos dos tambores e percussões, das letras e melodias, dos embalos corporais e artísticos, a fonte para que seu cotidiano não se torne letal, ao contrário, se fortaleça, inspire e respire nutrientes para a vida verdadeira, e para todos e todas. 
Sonhar uma vida melhor já é parte do movimento que faz acontecer, que retira forças do próprio chão, de um ethos que é estruturado na solidez que vem dos sinais já vivenciados por seus antepassados e na luta cotidiana desse povo. O ethos de uma pessoa, de um grupo, de um povo, é como uma morada, um eixo referencial, que se torna orientador de seu pensar e de seu agir. Situa-se no nível ontológico. É como uma base, uma matriz de percepção, de onde vemos e avaliamos as situações.

A partir dessa consideração, convidamos a pensar não apenas no ethos do povo brasileiro que constrói e bebe na fonte do samba a sua própria esperança, mas a pensarmos no ethos de que nos faz ser humanos, perceber a vida e atuar em cada realidade. E podemos ainda nos integrar na perspectiva de um ethos mundial, não apenas a morada humana, mas a morada de todas as criaturas, a casa de todos, a casa comum, como aponta o Papa Francisco em sua Encíclica Laudato Si. Sendo morada de todas as criaturas, ela nos pede que cuidemos de cada dimensão dessa morada, em uma atitude zelosa, amorosa, fraterna. É o inteiro planeta Terra, feito ethos-Casa Comum.

O urgente desafio de proteger a nossa casa comum inclui a preocupação de unir toda a família humana na busca de um desenvolvimento sustentável e integral, pois sabemos que as coisas podem mudar. O Criador não nos abandona, nunca recua no seu projeto de amor, nem Se arrepende de nos ter criado. A humanidade possui ainda a capacidade de colaborar na construção da nossa casa comum. (Francisco, LS, 2015: 13)

A esperança nos fala de um dinamismo que imprime à vida uma articulação entre passado, presente e futuro. Nesse sentido, falar de esperança é falar do cotidiano. Um cotidiano dinamizado por dois olhares: um olhar fundado na memória que sinaliza a certezaesperança e outro olhar voltado para o tempo presente. Só que, da mesma forma que nossos dois olhos confluem em uma única imagem, aqui também há um processo que dialoga e registra uma única imagem: traz para o cotidiano tanto a fundamentação e o horizonte provenientes desta certeza-esperança, como a análise dos sinais dos tempos e a busca de atitudes de aproximação cada vez maior com o sonho de vida plena para todos e todas.

Na perspectiva da experiência religiosa cristã, a esperança é uma virtude teologal, o que remete a compreensão escatológica, ou seja, o ser humano que se abre ao futuro absoluto. Mas como abrir-se ao futuro em um tempo no qual as narrativas de sentido são tão escassas? Sim, misteriosamente, ou mistagogicamente, como eu prefiro dizer, nosso povo abre-se ao futuro na certeza-esperança de ser conduzido e sustentado pela graça oferecida por Deus como promessa e como possibilidade real e, portanto, começando na história e apontando para sua plenitude. (Manzatto e outros, 2009, p. 135) 
Sim, digo mistagogicamente, porque quando compreendemos que a graça divina sustenta e orienta a historia, podemos também ousar uma interpretação de que a expressão plena de esperança que encontramos em algumas composições do samba brasileiro tem duas mãos que se integram: é acolhida e resposta de fé de um povo que fundamenta seu cotidiano neste diálogo entre o divino e o humano. Mistagogia é tanto inspiração como a ação de deixar-se conduzir pela graça misteriosa e amorosa de Deus, que vai tecendo um diálogo com cada pessoa, com cada comunidade. É como um eco que expressa esse diálogo, é mediação entre a ação divina e a realidade pessoal, histórica e social. ${ }^{6}$

Além dessa dimensão presente nas composições e nas melodias, outra característica presente no samba brasileiro que torna esse processo mistagógico é a dimensão litúrgica. Esse é um lugar de excelência no processo integrador que o samba promove, pois na sua força simbólica integra corpos, vozes, ritmos, sons, vestes, objetos, danças, rituais. Esses elementos não são apenas um conjunto funcional, mas ações simbólico-religiosas que conduzem os integrantes a uma participação plena, que une pessoa-comunidade, passado-presente-futuro, estética-ética, local-global, história-natureza.

Derivado do lundu e do jongo, trazido pelos negros escravizados e traficados de Angola e do Congo, o samba já recebeu muitos nomes e variações rítmicas - dissemba, massemba, semba, batuque, samba de roda, samba de breque, samba de bumbo, samba rural, samba rock, partido alto, samba enredo, gafieira, samba exaltação, pagode. Está presente no solo brasileiro, reside no inconsciente e cotidiano do nosso povo, mesmo cientes de que cada lugar, cada comunidade de samba tem sua peculiaridade, pois são muitos os brasis onde o samba se expressa.

Nesse dinamismo, nosso povo sofre e sonha. Sofre injustiças e sonha com um mundo de justiça. Sofre desumanidade e sonha com a fraternidade. Sofre com as desigualdades que violentam a dignidade da vida e sonha com o bem viver que a todos abraça igualmente. Ao partir da perspectiva utópica, ela mesma mobiliza todo o organismo na direção do projeto comum. Ela cria as possibilidades, renova estratégias, avalia e propõe as pequenas realizações históricas em um chão nada iludido, ao contrário, construído no amadurecimento que vem da luta cotidiana, do chão ensanguentado e dolorido, mas também dos sinais de semeadura e fecundidade que alimentam e animam a esperança.

\footnotetext{
${ }^{6}$ Para aprofundar o tema da Mistagogia, conferir o trabalho de minha autoria. COSTA, R. F. Mistagogia Hoje: $O$ resgate da experiência mistagógica dos primeiros séculos para a evangelização e catequese atuais. São Paulo: Paulus, 2014
} 


\title{
1. A esperança instaura um novo olhar
}

Para tratarmos a esperança como fundamento e orientação presentes no povo brasileiro, caminharemos por algumas composições do samba nacional. Será essa poesiareveladora que nos conduzirá ao longo desse artigo.

Iniciaremos com o samba de Luiz Carlos da Vila, Por um dia de graça. Foi composto em 1980, para o Grêmio Recreativo de Arte Negra e Escola de Samba Quilombo, um centro de resistência da cultura popular.

Passeie devagar pelos versos, pelas palavras-convite-convocação, pelo discernimento e, principalmente, pela esperança semeada.

\author{
Um dia, meus olhos ainda hão de ver \\ Na luz do olhar do amanhecer sorrir o dia de graça \\ Poesias, brindando essa manhã feliz \\ Do mal cortado na raiz do jeito que o mestre sonhava \\ O não chorar e o não sofrer se alastrando \\ No céu da vida, o amor brilhando, a paz reinando em santa paz \\ Em cada palma de mão, cada palmo de chão, semente de felicidade \\ O fim de toda a opressão, o cantar com emoção, raiou a liberdade \\ Chegou o áureo tempo de justiça \\ Ao esplendor, do preservar a natureza, respeito a todos os artistas \\ A porta aberta ao irmão de qualquer chão, de qualquer raça \\ O povo todo em louvação por esse dia de graça
}

Luiz Carlos da Vila principia com o sonho, com a utopia. Que terreno será esse? É possível sonhar em meios às adversidades? Sim, pois a esperança é fundamento ontológico, estrutural. O ser humano não coincide com sua existência concreta. Ele sonha, aspira o novo, aventura-se, corre riscos, se angustia com os limites, transgride, vai além. A tensão dialética entre o que já experimentamos e o que ainda temos pela frente dinamiza e potencializa o momento presente.

Nesta composição podemos observar a passagem da dimensão pessoal à dimensão comunitária. O sonho é para todos, o desejo é orientado para a humanidade e para o cosmos. A esperança é gerada no chão da história, mas supera esses limites, e esse mesmo chão se torna fecundo de escolhas e projetos que dão sentido ao hoje, porque o amanhã é certezaesperança.

Mas vejamos um detalhe implícito nestes versos. O poeta supõe sonhar, mas também o compromisso com o sonho. É um sonho que convoca. Ao trazer à visão do futuro sua realização já inaugura o fazer-acontecer o sonho, o compromisso cotidiano, ético e comunitário. A esperança é como uma mola propulsora de novos projetos. Ela dá sentido ao hoje, dá sentido ao avaliar, escolher, imaginar e construir. Usando um conceito muito materno 
e também gerador de vida nova, podemos dizer que a esperança engravida o ser humano, possibilita um processo de abertura dialógica para a dinâmica da vida e da história e na qual ele se insere como co-participante.

Esse samba é cantado como um hino. Percorre as gerações chamando para que a dureza do cotidiano não seja limitadora, e sim impulsionadora de novas ferramentas internas, que mobilizam o pessoal e o comunitário. O samba fala em dia de graça como um dia pleno, no qual não há lugar para portas fechadas, para opressão, para lágrimas e sofrimentos, para nenhum mal. É o Gênesis bíblico, é o paraíso sonhado, é a releitura que nosso povo faz do processo de resgate da terra prometida e da promessa sagrada que abarca todos os seres humanos, todos os seres criados, todo o cosmos.

\section{O solo fecundo experimentado no cotidiano}

Nessa segunda chave de leitura nos dedicamos à percepção do enraizamento no cotidiano, no chão como solo fecundo e, muitas vezes, trazendo o lamento como forma de oração, que faz memória da dor e, ao contar a história, resgata suas raízes, as lutas dos ancestrais, como na obra prima de Paulo Cesar Pinheiro e Mauro Duarte, composta em 1976: Canto Das Três Raças

\footnotetext{
Ninguém ouviu um soluçar de dor no canto do Brasil.

Um lamento triste sempre ecoou

desde que o índio guerreiro foi pro cativeiro e de lá cantou.

Negro entoou um canto de revolta pelos ares

no Quilombo dos Palmares, onde se refugiou.

Fora a luta dos inconfidentes pela quebra das correntes.

Nada adiantou.

E de guerra em paz, de paz em guerra,

Todo o povo dessa terra quando pode cantar, canta de dor.

E ecoa noite e dia: é ensurdecedor.

Ai, mas que agonia o canto do trabalhador...

Esse canto que devia ser um canto de alegria

soa apenas como um soluçar de dor: ô ô ô ô ô
}

Esse samba tem como inspiração e fundamento o enraizamento histórico do povo brasileiro. Ao trazer formação racial, evoca a consciência de um ethos comum e, ao mesmo tempo, a solidariedade na historia comunitária. Ir às raízes é reunir duas dimensões fundamentais para o ser humano, a identidade e a comunidade, a identidade e a participação.

Ao perceber identidade e comunidade em íntima relação, a consciência de comunidade humana como comunidade de sentido se torna o eixo referencial para o enraizamento cotidiano. Passado, presente e futuro estão entrelaçados, como um único tecido social e 
histórico. $\mathrm{O}$ destino comum passado é solo fecundo para o destino futuro a ser construído. $\mathrm{O}$ samba resgata as fontes do povo brasileiro e, com isso, nos faz beber nas fontes primeiras, nas águas mais puras, que criam, nutrem e alimentam a história de cada dia.

Não, não é um simples lamento, não são lágrimas vãs. São lágrimas que fecundam o novo, porque estão densas de consciência do destino comum, pessoal e comunitário. Estamos diante das forças de religação, que integram até mesmo o que foi destrutivo, e focam na sobrevivência, na continuidade, em uma ética solidária. Nessa medida, quando nosso povo se sente unido, solidário, fraterno, amoroso, é capaz de enfrentar junto a construção do sonho comum.

Religar é refazer laços pessoais e comunitários que são tornados solitários e alienados pelo sistema no qual estamos inseridos. Enraizar identidade e comunidade é deixar com que a seiva volte a nutrir os projetos. Precisamos de solidariedade, de amizades, de construção de vínculos, para que não nos sintamos deslocados e descolados uns dos outros e, com isso, nossos sonhos pareçam impossíveis.

Podemos olhar o mundo desencantado, sem rumo, imerso nas impotências e nas dores. Os sinais de morte parecem nos cercar de todos os lados, sugando nossas energias mais profundas, e até mesmo nos fazendo perder a fé. O lamento triste, o soluçar de dor que não é ouvido, ao ser proclamado e cantado aos quatro cantos do mundo, tira do silêncio que cria impotência, que cala os corpos de tantas brasileiras e brasileiros. A verdadeira esperança brota nesses mesmos corpos. Como nos diz Edgar Morin:

Ela é verdadeira justamente porque se afirma em um mundo desencantado. É a confiança nos recursos, na invenção, no engenho, na criatividade humana. É manter os ímpetos, as aspirações por uma nova vida, é ficar móveis e mobilizáveis. O contrário da esperança não é a lucidez, - o desencanto -, mas a resignação. (Morin, 2001, p. 56)

E por falar em enraizamento cotidiano e histórico, a Escola de Samba Acadêmicos da Mangueira, trará para a avenida no ano de 2019, a história das mulheres negras de nosso solo fecundo e sofrido, especialmente na paixão, vida e morte da vereadora Marielle Franco, assassinada em 14 de março de 2018. O samba foi batizado como Eu quero um Brasil que não está no retrato e a composição brota da ala de compositores da Mangueira: Deivid Domênico, Tomaz Miranda, Mama, Marcio Bola, Ronie Oliveira e Danilo Firmino.

Brasil, meu nego,

deixa eu te contar a história que a história não conta

$O$ avesso do mesmo lugar na luta é que a gente se encontra

Brasil, meu dengo, 


\author{
a mangueira chegou com versos que o livro apagou \\ Desde 1500 tem mais invasão do que descobrimento \\ Tem sangue retinto pisado atrás do herói emoldurado \\ Mulheres, tamoios, mulatos: \\ eu quero um país que não está no retrato \\ Brasil, o teu nome é Dandara, tua cara é de cariri \\ Não veio do céu, nem das mãos de Isabel \\ A liberdade é um dragão no mar de Aracati \\ Salve os caboclos de julho, quem foi de aço nos anos de chumbo \\ Brasil, chegou a vez de ouvir as Marias, Mahins, Marielles, malês \\ Mangueira, tira a poeira dos porões \\ $\hat{O}$, abre alas pros teus heróis de barracões \\ Dos Brasil que se faz um país de Lecis, jamelões, \\ são verde-e-rosa as multidões
}

Exaltando a história que não é contada nos livros, mas que é a estrutura de nosso povo, este também é um samba no qual a identidade é firmada com consciência, soberania e movimento de vida, que atinge o cotidiano e o futuro.

A vida de Marielle e a tragédia que a atingiu se torna uma experiência pascal, afeta o chão da história brasileira e provoca, mais uma vez, a pergunta sobre o sentido do existir. Qual será nosso destino? Qual o lugar dos projetos de humanização e dos sonhos comuns? Vale à pena perseverar? Como compreender o assassinato das vidas que se doam para todos tenham vida verdadeira?

Este samba evoca não apenas a memória de Marielle Franco, mas das mulheres que doaram suas vidas e foram ceifadas no seu cotidiano, nos seus sonhos. Contudo, nem por isso, a semeadura é vã. Suas vidas se tornam matéria prima e latente no solo brasileiro.

Ao contrário do individualismo vigente em muitos setores da sociedade moderna, esta compreensão nos fala de proximidade relacional, de histórias construídas coletivamente. É a substituição do individualismo pela corresponsabilidade. Por isso mesmo há uma integração profunda entre memória pessoal e coletiva, entre história pessoal e coletiva. Ou seja, as histórias de vida pessoais são compreendidas como um conjunto de histórias que antecedem cada pessoa, vividos não apenas pela pessoa que narra, mas constituinte de sua biografia, de sua identidade e pertencimento.

Estamos diante de uma das dimensões proféticas do povo brasileiro, pois, ao se compreender como identidade pessoal e coletiva, como corpos e vidas de muitas vozes e histórias, abraçam pessoal e comunitariamente as causas de grupos, etnias, expressões religiosas, escolhas diversas com, por exemplo, a causa da luta contra o extermínio da juventude negra, pobre e periférica; a luta pela justiça no campo, pela dignidade dos povos indígenas e quilombolas; as lutas contra qualquer tipo de intolerância. 
Sendo assim, fazer memória da vida doada-ceifada do povo negro, em solo brasileiro, não é apenas celebrar, mas também atualizar o que move e dá sentido à vida desse povo. Mais uma vez nos vemos diante de uma fonte de vida nova em meio à dor que o momento presente imprime ao olhar. Fonte é nutrição, é água cristalina, potencializa o futuro e aponta para a esperança. Vidas-fonte são vozes que surgem de todos os lados dizendo que o futuro converge para o amor radical, mesmo com nossos encontros e desencontros.

A convocação que emerge dessas vidas-fonte é que superemos a centralidade do indivíduo e avancemos para a compreensão de pessoa, constituída pelas relações com os outros, com o mundo, com a história, com todo o ambiente natural e cósmico. Este é um discernimento ético, e nos impele à compreensão de que as vidas ganham relevância e qualidade quando transcendem os limites individuais, assumem as situações desumanizantes e procuram interferir para a superação dos limites, em busca da plenitude da vida para todos e todas.

\section{O Sagrado presente na história, revelador e misterioso}

Nossa terceira chave de leitura será a percepção de presença do Sagrado como próxima, embasando as esperanças, as escolhas e orientações na histórica concreta do povo brasileiro.

O Samba Juízo Final, composto em 1973 por Nelson Cavaquinho e Élcio Soares, expressa um julgamento da história e também a esperança aparece no desejo de presenciar este evento no qual a vitória é do amor. Também podemos perceber este desejo no coração do povo sofrido e esperançoso de novos dias: o desejo de justiça, de que haja uma espécie de avaliação final, na qual o mal seja condenado e queimado definitivamente. A canção não fala de julgamento de pessoas, e sim deste grande duelo entre o bem e o mal: dilema que desde os primeiros tempos filosóficos permeia as reflexões humanas em busca de possibilidades que tragam consolo em momentos em que a história parece tão fecunda de sinais de morte e de crueldade.

O sol há de brilhar mais uma vez, a luz há de chegar aos corações Do mal será queimada a semente, o amor será eterno novamente É o Juízo Final: a história do Bem e do Mal Quero ter olhos pra ver a maldade desaparecer 
Seguimos nossa estrada, sendo conduzidos agora por um samba que exalta a explosão de alegria: $E$ hoje, da Escola de Samba União da Ilha, apresentado na passarela do Carnaval de 1982, e composto por Gustavo Baeta Neves, conhecido como Didi e por Mestrinho.

\author{
A minha alegria atravessou o mar e ancorou na passarela \\ Fez um desembarque fascinante no maior show da Terra \\ Será que eu serei o dono desta festa \\ Um rei no meio de uma gente tão modesta? \\ Eu vim descendo a serra cheio de euforia para desfilar \\ O mundo inteiro espera: hoje é dia do riso chorar \\ Levei o meu samba pra mãe-de-santo rezar \\ Contra o mau olhado carrego o meu Patuá \\ Acredito ser o mais valente nesta luta do rochedo com o mar \\ É hoje o dia da alegria e a tristeza nem pode pensar em chegar \\ Diga espelho meu se há na avenida alguém mais feliz que eu
}

A composição é marcada pelo movimento, pelo dinamismo impulsionado pela alegria que atravessa o mar. É dinâmica pascal, de renovação, de avançar em meio às turbulências e encontrar porto em meio à sua gente valente. A avenida é símbolo da festa da vida, da certezaesperança que move o mundo inteiro.

Nas entrelinhas podemos perscrutar que a festa final ainda não é alcançada, mas cada celebração na avenida é sinal de proximidade com a plenitude. Nos fala de um mistério que se aninha no coração humano, em cada passo: um mistério presente-ausente, reveladoescondido, no segredo da terra e na sua própria dinâmica.

No samba aparecem os recursos religiosos para proteção desta festa-simbólicaescatológica. A consciência da presença do mal, do mau olhado, do choro, da luta cotidiana, é assumida e entregue na confiança religiosa. Em um campo marcado por situações-limite, sofrimentos, mágoas, o samba traz a consciência da presença do mal e, ao mesmo tempo, a necessidade de não se deixar limitar por essas situações. Reconhece e entrega, coloca na força espiritual a libertação do sofrimento, e segue para a avenida. O ritual comunica a ação transformadora divina na luta contra o mal. Ao entregar à dimensão espiritual, pode seguir livre e fortalecido na direção da certeza-esperança, e a alegria invade a alma e pode explodir na avenida.

Mais uma vez podemos vislumbrar a mistagogia, o caminho conduzido pelo mistério presente na realidade e que mobiliza o sonho. Essa integração fortalece interiormente e nutre o caminho a ser realizado. 
Para finalizar nossa reflexão selecionamos dentre tantas expressões do samba brasileiro, o samba composto por Sombrinha, Zeca Pagodinho e Jorge Aragão em 1983: Mutirão de Amor.

Ele integra as três chaves de leitura que trouxemos ao longo do texto: a esperança, o enraizamento no cotidiano e a proximidade do Sagrado. Vejamos a beleza da composição.

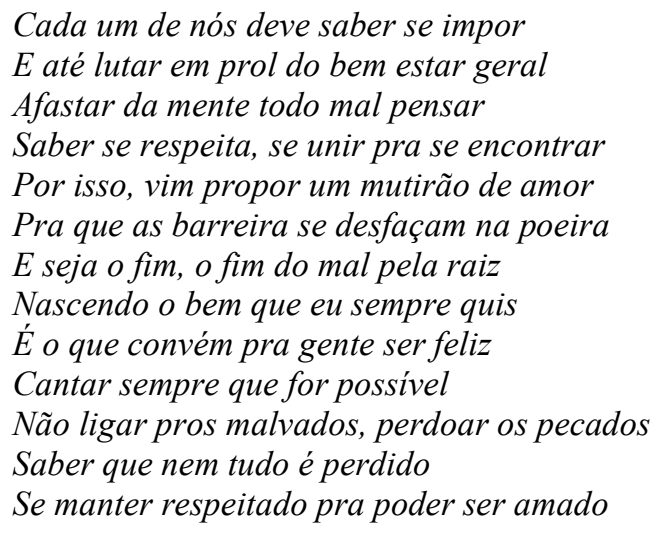

Estamos diante de uma integração dinâmica entre caminho e meta, entre desejo e realização, entre o humano e o divino. Ele se dá por meio da consciência, da sensibilidade, da empatia, da identidade participante, enraizada no chão da história e orientada para o futuro que a todos abraça no sonho de plenitude. Por isso mesmo, o samba chega como um mestre que reforça a confiança nos passos já trilhados e convida a seguir. Efetivamente, é um convite performático, pois reúne os sinais que convidam, convocam a pessoa e a comunidade reunida em torno do ritual do samba. É uma experiência viva.

$\mathrm{Na}$ composição tudo convida a uma centralidade, ela é marcada pela confiança na vida, no mistério que embasa e dirige o viver. Observemos que há uma nova dimensão de tempo e de espaço passeando pelos versos. Não se trata de um tempo linear, e sim de um tempo contínuo. É um tempo real, mas também um tempo meta-histórico, escatológico. E a comunidade reunida se percebe participante desse mistério que carrega maternalmente a história e, por isso mesmo, é capaz de ser protagonista. A experiência estética-simbólicahistórica-metahistorica potencializa a revisão da existência, a reinterpretação do mundo em uma nova ótica e, consequentemente, construindo novos significados para as escolhas e o agir cotidiano. 


\section{Na cadência da fé na vida}

Nossa contribuição é de, humildemente, nos deixarmos conduzir pela sabedoria que emana dessa experiência simbólica. A poesia está imersa em um caldo de espiritualidade e escuta profunda das vozes que ecoam do chão, orientando o olhar, a interpretação e o fazer cotidiano e escatológico. Nesse sentido é que aprendemos que essa experiência não se reduz a um evento, a um momento temporal, mas que tem consequências cotidianas, que integram a pessoa e a comunidade, o agir local e condicionado como uma perspectiva global e cósmica. Enfim, é uma experiência que mantém a fecundidade do sonho de vida plena para toda a criação.

O convite é não ocuparmos o lugar da impotência e das limitações da condição humana e cósmica, mas, ao contrário, inscrevermos o cotidiano nas potencialidades do já vivido, do já experimentado, do que é estruturado na história da humanidade e aberto à libertação integral humana e cósmica.

Essa esperança celebrada é força geradora de vida nova. Sua dimensão estética e litúrgica conduz à integração plena, no sentido de ir até as raízes de seu ser, das razões de seu existir e de suas finalidades históricas e meta-históricas. Ela coloca em movimento o ser humano integral e o corpo-comunitário que a realiza, confiante no mistério que a todos envolve e constrói a consciência de que é histórico, portanto, dinâmico e processual. O passado e o presente ganham sentido simbólico, são portadores de mensagens e também de mistérios que fundamentam a confiança, a acolhida e a resiliência.

\section{Referências Bibliográficas:}

E. BLOCH, O Princípio Esperança. Rio de Janeiro: Contraponto/Ed. UERJ 2005-2006 CAMUS, A. O mito de Sísifo. Ensaio sobre o absurdo. Livros do Brasil: Lisboa, s/d. COSTA, Rosemary Fernandes da. Mistagogia Hoje: O resgate da experiência mistagógica dos primeiros séculos para a evangelização e catequese atuais. São Paulo: Paulus, 2014 FRANCISCO, Papa. Carta Encíclica Laudato Si' Louvado sejas. Sobre o cuidado da casa comum. São Paulo: Paulinas, 2015.

MANZATTO, A., PASSOS, J. D. e VILLAC, S. De esperança em esperança. Escatologia. São Paulo: Paulus, 2009

MORIN, E. A cabeça bem-feita: repensar a reforma, reformar o pensamento. Rio de Janeiro: Bertrand Brasil, 2001. 


\title{
Kathakali: a inter-relação entre teatro e ritual
}

\author{
Raquel Belém de Andrade da Silva \\ raquelbelemm@gmail.com ${ }^{7}$
}

\begin{abstract}
Resumo: Kathakali é um dos Teatros Clássicos mais popular da Índia. Por aproximadamente 400 anos tem realizado suas performances a partir de um ritual religioso onde os atores interpretam deuses em um palco repleto de símbolos e crenças. Por isso, Kathakali é reconhecido pela sua estética, técnica e devoção, seguindo um ritual dramatizado capaz de unir teatro e dança em uma única performance restrita apenas a homens, em encenações que duram toda a noite até o raiar do dia. Sendo assim, a presente pesquisa analisa a sacralização do teatro-dança Kathakali. Para tanto, foi realizada revisão bibliográfica a fim de investigar sua origem, relevância e, principalmente, a inter-relação entre sua performance e a religiosidade hindu expressa através de rituais. Destaca que a Índia, por ser um país de amplo pluralismo religioso, faz também do seu palco um local sagrado. Desta maneira o Kathakali, que é uma expressão artística hindu, faz da sua arte uma oferenda através do ator sacerdote. É o teatro sagrado resistindo o tempo e a modernidade através do Hinduísmo.
\end{abstract}

Palavras chaves: Kathakali; Teatro sagrado; Hinduísmo; Teatro ritual; Índia

\section{Introdução}

A história e cultura indiana tem sido objeto de investigação em diferentes campos de estudo, tais como: História, Sociologia, Antropologia, Filosofia, Geografia, Artes e Ciências das Religiões. O ocidente vislumbra-se com seus mistérios e sabedoria construídos através dos séculos.

A Índia também é um país de uma notável pluralidade religiosa, entretanto o Hinduísmo é o sistema religioso que mais tem adeptos na Índia. Segundo Glaab

O hinduísmo é um termo genérico para as religiões indianas, ou que se originaram na índia, fundamentadas nos escritos mais antigos da Índia, os Vedas elou que não questionam a validade da classe sacerdotal indiana (brâmanes) (GLAAB, 2012, p.2).

Também é notável que na Índia arte e religião não se separam. Espetáculos de dança, música e teatro apresentados em diferentes lugares da Índia levam ao palco criações artísticas e rituais que unidos resistiram ao tempo, e ainda hoje são realizados por adeptos da tradição hindu.

Por isso, quando falamos em Teatro Clássico da Índia logo vem a mente uma estética repleta de religiosidade. Um palco onde os atores com seus figurinos coloridos e maquiagem forte e cheia de detalhes encenam lutas entre deuses e demônios transmitidos pelos principais textos védicos.

Segundo Santo (2011), entre os diferentes estilos de Teatros Clássicos da Índia que 
mais se destacam estão o Therokoothu e Kathakali. Ambos são produções artísticas resultantes de várias gerações que se dedicaram ao aperfeiçoamento da dramatização em cena.

Diante desta notável relação entre arte e teatro este artigo busca investigar a interrelação entre teatro e ritual existente no teatro Kathakali. Para isto foram feitas pesquisas em diferentes fontes de informação como o portal Capes, Sielo e Google Acadêmico, buscando artigos e outros materiais que pudessem contribuir para o embasamento teórico. Sendo assim, cabe ressaltar que foram realizadas a leitura de autores das seguintes áreas: Ciências das Religiões, Teatro e Sociologia.

Segundo Leger, Max Weber considera que "A religiosidade mágica, à medida que valoriza todos os meios possíveis para entrar em contato com a divindade e agir sobre ela, mantém relações íntimas com a esfera estética, por meio da utilização da música, da dança[...] para se aproximar dos deuses" (LEGER, p.95).

Desta maneira, o presente estudo visa observar a relação arte e religião presente na Índia, o teatro Kathakali e sua performance como ritual sagrado e, finalmente a sacralização presente em sua dramatização.

Percebemos com isto que o Natyasastra não era voltado apenas a uma casta. Neste caso, seria a democratização de uma arte religiosa feita para todos. Tornando-se este um dos grandes motivos de seu uso, também, pelo teatro ocidental.

\section{Arte e religião na Índia}

Uma das características peculiares da Índia é a sua pluralidade religiosa. Um país que tem entre sua população, cristãos, muçulmanos, e principalmente hindus que são a maioria população. 


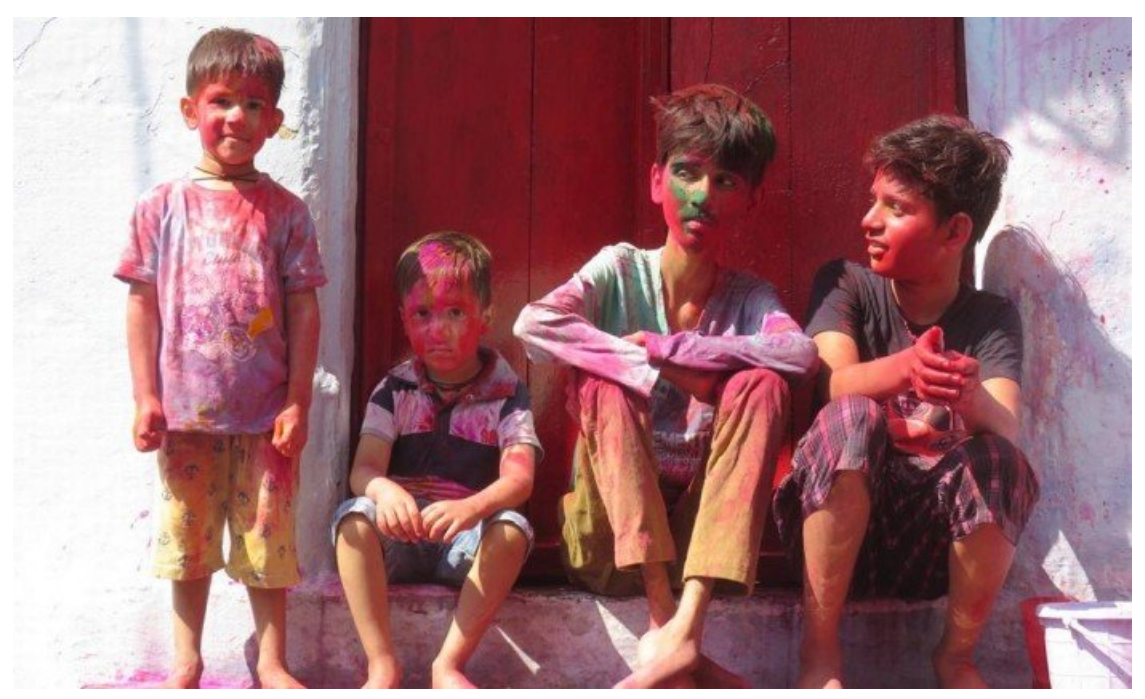

Figura 1. Holi, festival das cores na índia. Fonte: https://oglobo.globo.com

Entre deuses que fazem parte do conjunto de tradições religiosas denominada Hinduísmo encontramos Saraswati que é deusa (esposa do deus Brahma) da música, dança, conhecimento e teatro. Ela segura um instrumento musical, conforme a imagem.

Existem diversas divindades femininas (devīs) que sao citadas nos Vedas; Sarasvatī e uma das mais importantes delas. Muitas das divindades vedicas estao associadas a fenomenos naturais - como Sūrya, que esta associado ao Sol, Agni que esta associado ao fogo e Vāyu que esta associado ao vento. Sarasvatī esta associada a um grande rio indiano, que tem esse mesmo nome; mas Sarasvatī nao e meramente a designação de um rio, assim como Sūrya nao e simplesmenteo Sol, nem Agni e somente o fogo e nem Vāyu apenas o vento.(Bianchini,2014)

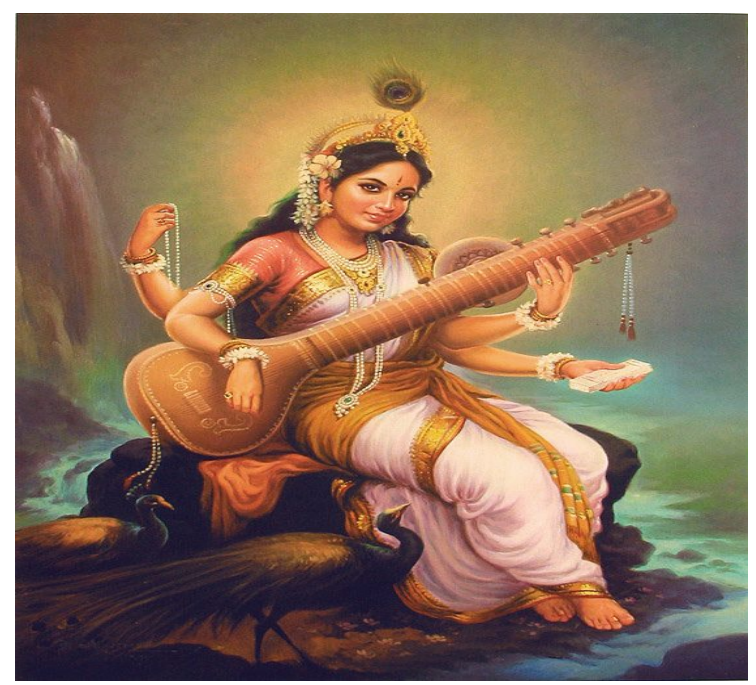

Figura 2 Saraswati 
Em relação ao referencial artístico, “diversas artes clássicas declaram sua origem no Nāţyaśāstra, como as danças clássicas Bharatanāţyam e o Kathak; os teatros clássicos Kūţiyaţ̧̧am e Kathakali” (PEREZ JUNIOR, 2011, p.14)

Sua origem está relacionada a uma experiência religiosa vivida por um místico chamado Barata Muni. Sobre este acontecimento Mota afirma que

\begin{abstract}
Do começo do tratado, temos a inserção da atividade do performer em uma ambiência mítica e cósmica. Segundo o relato, em um passado primordial, o povo deste mundo, imerso em profunda selvageria, suplicou aos deuses algo que não só trouxesse sabedoria como também deleite tanto aos olhos quanto aos ouvidos. Brahma os atendeu e integrou, em um espetáculo só, todas as artes e ciências, formando um espetáculo de palavras, música, movimentos, atuação e cenotécnica que requer para sua efetivação pessoas inteligentes, sábias, diligentes e com autocontrole (MOTA, 2006).
\end{abstract}

Por possuir uma visível ligação com os textos védicos sagrados, é considerado por muitos como o quinto Veda. Valera afirma que

\begin{abstract}
ele foi escrito provavelmente entre os séculos I a C. e I.V.d.c. por Bharata Muni e constituiu-se de preceitos sobre composição e representação da dança, da música e do teatro. Versando sobre a arte de escrever ou encenar peças teatrais, ele representa os princípios constitutivos das músicas, da dança e da literatura indiana. (VALERA, 2015, p.67)
\end{abstract}

Com isso "Bharata assentou a pedra fundamental da arte do teatro hindu; dispôs todas as suas regras artísticas, sua linguagem e suas técnicas."(BERTHOLD, 2014, p.33)É a representação dramática como manifesto da experiência religiosa do povo hindu.

Os rituais existentes nas diferentes tradições do Hinduísmo não são realizados apenas em seus cultos, mas misturam-se a realidade da população no seu fazer diário, no decorrer de sua história.

Do levantar ao deitar, cada ação realizada durante o dia é repleta de devoção aos seus deuses. Por isso, o povo indiano é considerado um dos povos mais místico. Homens, mulheres, crianças e idosos vivem cultuando seus deuses desde o levantar até deitar. Em relação aos ritos religiosos Vilhena afirma que

Propõe-se o entendimento de ritos religiosos como ações simbólicas, coletivas ou individuais, embasadas em sistemas de crenças que postulam a existência de modo único, alternado ou combinado, de forças ou energias que podem ser tanto internas como externas aos sujeitos (VILHENA, 2004,p.514). 
Nota-se que na índia os rituais religiosos são repletos de cores e significados, orientados pelos escritos sagrados hindu, os vedas. Alimentos, flores, danças, música e sacrifícios de animais, são oferecidos aos seus deuses em devoção e agradecimento, tornando assim o momento único e envolvente.

É interessante verificar que o sacrifício védico é bastante original, pois consiste num banquete oferecido aos deuses. $\mathrm{O}$ fogo, a oferenda e os cantos sagrados fazem os deuses descer à terra, é-lhes então pedido que tomem lugar sobre a erva sagrada que se estende diante do altar e apresenta-se-lhes em abundância tudo o que pode alegrar os mortais, como bolos, arroz, leite, banha, carne de animais sacrificados e soma. É, igualmente, necessário alegrar os deuses com perfumes, música e danças (FRIAS, 2003, p.182)

O teatro Kathakali representa a união da arte com a religião. A cada cena o ator realiza um ritual visto pelo público que o assiste transmitir a mitologia conservada pelo povo.

\section{Kathakali}

O uso da arte como um caminho do homem religioso para encontrar e adorar seu deus é um fato observado em diversas culturas, seja através das músicas, danças de fertilidade, ritos de iniciação ou outros rituais sagrados.

A história do teatro mostra que desde a antiguidade o homem usa suas performances como instrumento de devoção em rituais religiosos. "Não somente os festivais de Dioniso da antiga Atenas, mas a Pré-história, a história da religião, a etnologia e o folclore oferecem um material abundante sobre danças rituais e festivais das mais diversas formas que carregam em si as sementes do teatro" (BERTHOLD, 2014, p.2).

Com o intuito de propagar a sabedoria védica da tradição hindu o teatro Kathakali tem realizado suas performances por aproximadamente 400 anos em Kerala, cidade situada no sul da Índia. Suas apresentações mostram através de personagens mitológicos (deuses e demônios) cenas repletas de beleza, movimentos e rituais. Contribuindo, desta maneira, para a cultura cênica do país. Ribeiro diz que:

$\mathrm{Na}$ Índia acredita-se que todo palco seja um local sagrado escolhido pelos deuses,onde a eterna luta entre o bem e o mal deve se repetir para sempre. O Kathakali, sendo uma arte essencialmente hindu, é conduzido como um ritual e tudo que é relacionado a ele é investido de algum significado religioso. $\mathrm{O}$ ator em cena tem consciência do simbolismo da performance enquanto cerimônia propiciatória normalmente em homenagem ao deus patrono do templo onde ocorre a performance - e da centralidade de sua atuação no contexto da oferenda. Sua aparição em cena, 
representativa de figuras mitológicas e divinas, encarna ideias e valores culturais que funcionam como eixos ao redor do qual orbitam as vidas da grande maioria da população da Índia e da audiência ali presente, em particular (RIBEIRO, 2013, p.88).

Ainda segundo Almir Ribeiro, as apresentações iniciam no final da tarde e atravessam toda a madrugada conforme imagem apresentada. Antes do seu início são feitos rituais para o preparo do templo e ao redor os músicos caminham anunciando que haverá expetáculo. $\mathrm{O}$ público já esta acostumado com a duração da apresentação e juntamente com uma forte disposição de passar a noite levam oferendas que são dadas aos atores. Isto porque ao representar um deus é considerado como o mesmo, recebendo no final da apresentação ofertas em adoração.

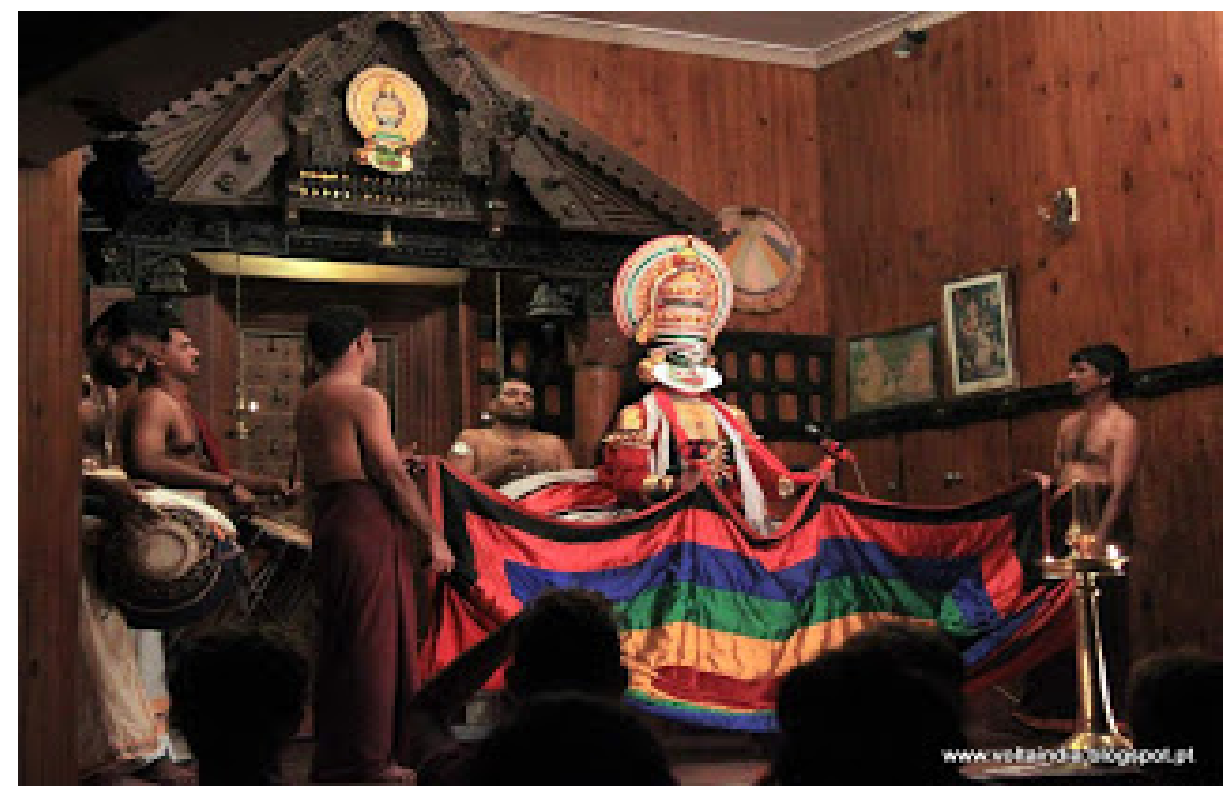

Figura 3. Apresentação do teatro Kathakali. Fonte: voltaindia.blogspot.com

Devido suas vestes apertadas, maquiagem feita com cores fortes e a responsabilidade de participar de um teatro religioso faz com que os atores tenham um envolvimento que vai além do interesse pela prática artística. 


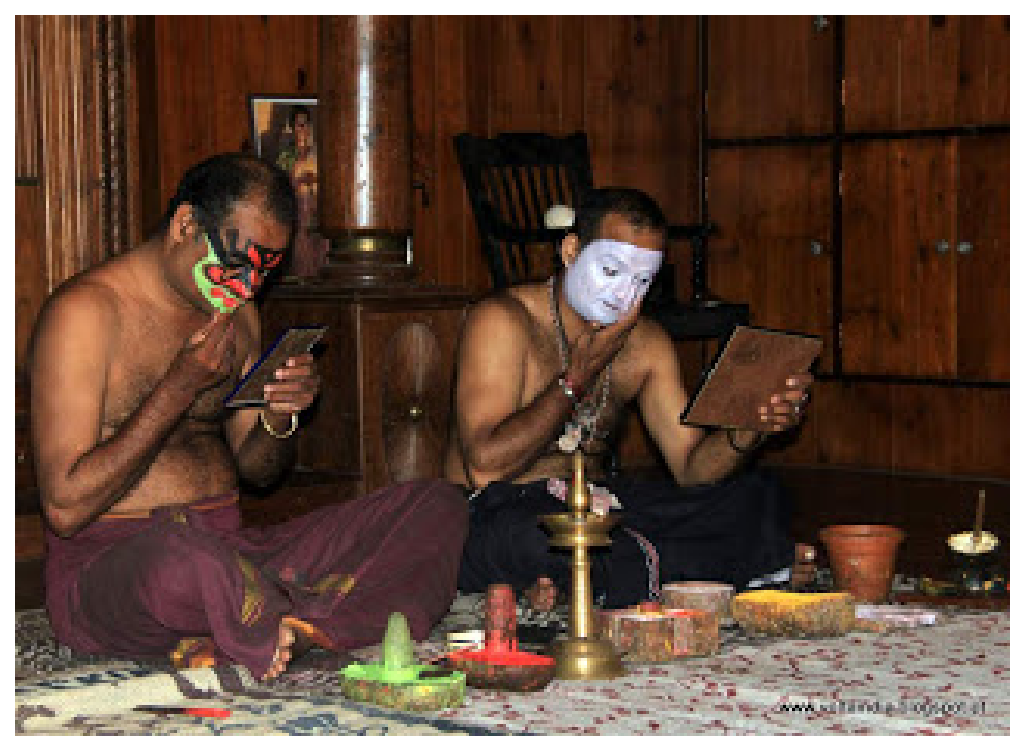

Figura 4. Preparo das maquiagens antes de iniciar o ritual. Fonte: voltaindia.blogspot.com

Interpretado somente por homens (observado através da imagem) o ator do Kathakali que também é um sacerdote mostra dentro e fora do palco toda a sua devoção. As técnicas, treinos e práticas religiosas que aprende desde sua infância levam-o ao extremo compromisso com o seu papel em sua vida diária.

Ao encarnar o personagem a partir de um corpo extra-cotidiano, as ações físicas, acompanhadas pelos ritmos musicais precisos, constroem partituras que se tornam um dos meios mais eficazes de transmissão da tradição hindu.

Um homem religioso que busca vivenciar através de sua arte uma experiência mística com seu deus. Para que isto ocorra de maneira plena dedica sua vida a arte, ao mesmo tempo que a oferece como oferta.

Por isso a energia que o ator de Kathakali busca em cena torna uma via de contato com o transcendente. Uma energia de um corpo devoto.

\section{Teatro Religioso}

Este homem religioso que almeja está constantemente em contado com seu deus, busca a partir de sua arte vivenciar uma experiência religiosa onde o transcendente pode ser interpretado em cena. Neste caso sua atuação torna-se uma oferenda ao mesmo tempo que encarna um deus e é adorado como tal.

Uma atuação teatral considerada pelos hindus como sagrada devido sua 
funcionalidade. É a religião unindo-se a arte em uma cultura onde "o homem religioso se esforça por manter-se o máximo de tempo possível num universo sagrado" (ELIADE, 2010, p.19).

Podemos destacar que esta ligação entre arte e religião chamou a atenção de Max Weber. Quando analisou o uso da estética por diferentes religiões concluiu que

\begin{abstract}
Do mesmo modo, há tanto relações estreitas quanto tensões entre religião e a esfera estética. A religiosidade mágica, à medida que valoriza todos os meios possíveis para entrar em contato com a divindade e agir sobre ela, mantém relações íntimas com a esfera estética, por meio da utilização da música, da dança, da arquitetura dos templos, dos ornamentos do culto para se aproximar dos deuses. Neste sentido, a religião encorajou vivamente a atividade artistica. Em contrapartida, para a ética religiosa da fraternidade e do rigorismo, a arte é suspeita porque, precisamente, é portadora de efeitos mágicos e de emoções que arriscavam provocar crise nas relações racionais com um deus ético. Contudo, à medida que as religiões queriam ser religiões de massa e da propaganda emocional, elas tiveram de fazer alianças com a arte e a ela se abrir (LÉGER, p.95).
\end{abstract}

Desta maneira podemos dizer que o uso da arte no culto a uma divindade não é uma exclusividade adotada pelo Kathakali. Muitas outras religiões utilizam a arte para comunicar ou catequizar o público.

\title{
5. Considerações Parciais
}

O homem através da sua história tem produzido diferentes estilos de arte com diversas finalidades. No caso do Teatro indiano, vemos claramente sua forte relação com a prática religiosa do hindu. Cada gesto na encenação é preparado para que o ator ofereça uma oferta de gratidão ao seu deus.

Partindo da observação do Teatro indiano como um teatro sagrado, constata-se que o entendimento deste teatro como um ritual é o resultado de uma arte que tem sua origem a mais de 400 anos e que traz em cena histórias que ligam o homem ao sagrado.

Este desejo de se manter em contato com o transcendente através da arte faz com que o ator vivencie a experiência religiosa onde o palco, a cena e as ações do sacerdote são considerados sagradas.

Por isso negligenciar a importância da relação entre arte e sagrado na cultura indiana é desconsiderar a trajetória histórica do povo e ignorar sua importância para a formação religiosa desta sociedade 


\section{Referências}

ABILIO JUNIOR, José. Estados emocionais (Bhava) e experiência estética (rasa) : os conceitos centrais da filosofia da arte indiana e alguns de seus desdobramentos. Juiz de Fora, 2015

Breve introdução à hermenêutica do capítulo 1 do Natyasastra: a criação Donatya; a construção do primeiro teatro; e o "recontar" do "paradigma' dos "três mundos" Religare 8 (1), 12-22, março de 2011

BERTHOLD, Margot. História mundial do teatro. São Paulo : Perspectiva, 2004.

BIANCHINI, Flavia. A deusa Sarasvatī no hino 6.61 do Rgveda. Cultura Oriental, v. 1, n. 2, p. 1-16, jul.-dez. 2014

CROATO, José Severino. As linguagens da experiência religiosa. São Paulo: Paulinas, 2001.

ELIADE, Mircea. O sagrado e o profano : a essência das religiões. São Paulo: Editora WMF, 2010

FRIAS, Hilda Moreira de. História e religião na Índia antiga. REVISTA PORTUGUESA

DE CIÊNCIA DAS RELIGIÕES - Ano II, 2003, n. ${ }^{\circ}$ 3/4 - 179-188

GOMES, Ricardo Carlos. DUARTE, Priscila de Queiroz. A dramaturgia do corpo no Teatro Indiano como visível poesia. Revista Brasileira de Estudos da presença. Porto Alegre v.7, n.1, p.154-183, jan\abr.2017

GOMES, Ricardo. A tradição do ator entre Oriente e Ocidente.

KUNG, Hans. Religiões do mundo : em busca dos pontos comuns. Campinas: Verus, 2004.

MOTA, Marcus. Natyasastra: teoria teatral e a amplitude da cena. Revista de História e Estudos Culturais. Vol. 3 Ano III n4

OTTO, Rudolfo. O Sagrado : um estudo do elemento não-racional na ideia do divino e a suaa relação com o racional. 1985

RIES, Julien. O sagrado na história religiosa da humanidade. Rio de Janeiro: Vozes,2017

SANTO, Denise Espírito. O teatro dança indiano: entre o clássico e o popular. Textos escolhidos de cultura e arte populares. Rio de Janeiro, v.8,N. 1, p.99-105.maio de 2001.

SCHECHNER, Richard. Performance e Antropologia de Richard Schener. Rio de Janeiro : Mauad, 2012.

VALERA, Lúcio. A mística devocional (bhakti) como experiência estética (rasa): um estudo do bhakti-rasāmR ta-sindhu de rūpagosvāmī .juiz de fora, 2015. 


\title{
O 'yoguin do séc. XXI' na música de BNegão e Walter Franco: uma nova
} categoria ontológica para matizar a experiência pós-tradicional de 'vida em

\section{aprendizado'}

\author{
The 'yoguin of $21^{\text {st }}$ century' in the music of BNegão and Walter Franco, a new ontological \\ category to qualify the experience post-traditional of 'life in learning'
}

Vinicius Tobias ${ }^{8}$

vinitobias00@yahoo.com.br

\begin{abstract}
Resumo: Esse trabalho tem como objetivo apresentar as conclusões da pesquisa realizada no mestrado em Ciência da Religião em Juiz de Fora intitulada "Os yoguins do séc. XXI: o aprendiz orientalista pós-tradicional na música de BNegão e Walter Franco". A pesquisa consistiu em um esforço de religiões comparadas a partir da interpretação dessas canções com atenção a seus motivos de agregação e disseminação de cosmovisões, identificando nelas, por sua coerência interna, algo como uma 'teologia' que permeia toda a obra dos compositores e que gravita em torno da narrativa sobre a atividade de um 'aprendiz orientalista sem mestres' nos tempos atuais. Assim, serão apresentadas as características gerais desse aprendiz cantado em ambas obras orgânicas seguida de sua comparação e da conceituação dessa categoria.
\end{abstract}

Palavras-Chave: Yoguins do séc. XXI, BNegão, Walter Franco, Orientalismo, Música

\begin{abstract}
This paper aims to present the conclusions of a research carried out in the master's degree in Science of Religion in Juiz de Fora entitled "The yoguins of de $21^{\text {st }}$ century: the post-traditional orientalist apprendice in the music of BNegão and Walter Franco." The research consisted of an effort of religions compared from the interpretation of these songs with attention to their motives of aggregation an dissemination of wordviews, identifying in them, by treir internal coherence, something like a "theology" that permeates all the work of the composers and that gravitates around the narrative about the activity of an 'apprentice orientalist without masters' in modern times. Thus, the general characteristics of this learner sung in both organic works will be presented, followed by their comparison and the conceptualization of this category.
\end{abstract}

Key words: Yoguins of $21^{\text {st }}$ century, BNegão, Walter Franco, Orientalismo, Música

\section{1 - O Yin e o Yang do Orientalismo na canção}

Walter Franco é um músico conceitual e experimental. Ele começa sua carreira na década de 1970 e segue ativo até hoje, embora de maneira mais recolhida. Autor de seis discos e alguns compactos, o compositor quase não encontra seu lugar na cultura de consumo e seu nome (não tanto suas canções) é bastante desconhecido do público em geral. No entanto,

\footnotetext{
${ }^{8}$ Mestre em Ciência da Religião pela Universidade Federal de Juiz de Fora, e doutorando em Ciência da Religião por essa mesma universidade.
} 
é tido em alta consideração pelos intelectuais, artistas e estudiosos da música. Isso por sua estética radical e seu trabalho conceitual de forte apelo poético e semiótico.

Já Bernardo Santos, o BNegão, ligado ao hip-hop e à cultura underground chega ao grande público na década de 1990 como um dos vocalistas e letristas do grupo de hip hop Planet Hemp, que militava (e milita, o grupo voltou a fazer shows em 2016, embora não haja novas composições) pela legalização da maconha. Com o fim da atividade do grupo, em 2001, BNegão começa seu novo projeto, o BNegão e os Seletores de Frequência. Ele desenvolve uma carreira solo cuja marca de modo de criação é a independência e a atividade de composição do som pelos músicos que o acompanham, formando um trabalho de construção estética que mistura tudo quanto existe de estilo considerado pelo grupo como 'negro': rap, hardcore, dub, groove e funk carioca. No som dos Seletores de Frequência todos esses estilos são mobilizados com o intuito de servir como base para letras prosaicas reflexivas e fortes escritas e cantadas pelo BNegão.

Nesse primeiro contraste já fica a imagem: de um lado, Walter Franco enquanto um músico escorregadio e evasivo, e isso se reifica pelo fato de seu trabalho semiótico se centrar no silêncio. De outro, de BNegão como portador de um som e de uma mensagem de fácil acesso, que dialoga mais com a cultura pop e que tem uma mensagem com maiores contornos a ser dita nas verdadeiras atividades oratórias e argumentativas que por vezes se caracteriza o rap.

De fato, as escolhas musicais de cada um desses compositores têm relações com certos impulsos de significação contidos em suas canções. BNegão, como será demonstrado, investe bastante em imagens, metáforas e modos de dizer que aludem à reencarnação e a uma concepção de karma como uma outra dinâmica energética dos acontecimentos. Em suas elaborações são visíveis semelhanças com a idéia Hindu de atman, ou seja: fundamento, substância, ou ainda, "eu-interior", "self perfeito". Isso acaba acontecendo por ser declaradamente legatário de um conhecido mestre de yoga, o Professor Hermogenes, 'mestre' (entre aspas por não ter estudado diretamente com ele) mais citado por BNegão em suas músicas e entrevistas. Para BNegão então é preciso ao indivíduo um trabalho espiritual que se centre em se conhecer, em alcançar quem a pessoa verdadeiramente é por traz da ilusão do ego. Somando ao fato de que esse conhecimento harmonizaria a vida e teria forte impacto na dissolução de tudo aquilo que representa a sustentação das injustiças sociais, isso por que o véu de Maya (ilusão) estaria suspenso ao se conhecer o verdadeiro eu como uno com Deus.

Em Walter Franco encontra-se evasão também em suas emanações religiosas, sendo que é com sutileza que trata de ciclos e de vazios (algo que pode ser mais encontrado na 
forma das canções do que nas letras), embora não se apresente evasivo quando se fala da medida a se tomar, em como se manter. Basta lembrar de sua música mais famosa, a letra na íntegra diz: "Tudo é uma questão de manter / a mente quieta / a espinha ereta / e o coração tranqüilo",9.

Ou seja, uma música enigmática em Franco, na qual o mais importante é silenciar sobre a natureza da realidade e trabalhar as suas próprias ações e percepções no sentido de melhora e esvaziamento de conceitos; ao passo que, em BNegão uma música mais palatável e conteudística, na qual a realidade é mais cognoscível e um trabalho mais racional deve ser feito para superar a ilusão e se atentar para a verdade do ser. Essas diferenças percebidas nos macro-processos estilísticos remontam à discordância fundamental hindu/budista entre atman e anãtman, ou seja, substância ou não substância. Essa diferença é também sentida na música, nas mudanças dos modos de formar que as constituem.

Essas equivalências opostas e complementares nos permitem brincar ao ver dois espíritos religiosos próximos, mas que se mantêm em extremos e desencontros de evasão/escrutínio argumentativo, vazio/composto de uma realidade sobre a qual se pode falar; baixa energia sonora/carga auditiva alta e sem momentos vazios. Tudo isso indica que estamos diante de dois momentos do que podemos chamar orientalismo na canção, mas de dois momentos opostos, no mesmo sentido em que o yin (sombra) é oposto de yang (luz). Essa formulação apresentada, além de ser um recurso textual de classificação, é também um espelho do papel encenado por esses personagens culturais. Pois quando Walter Franco se liga mais ao evasivo e ao vazio e BNegão à afirmação de uma realidade e da urgência da busca espiritual, acabam por reconstruir, nas religiosidades pós-tradicionais, a discordância fundamental pela qual se polarizam as tradições do oriente.

E porque o termo orientalista? Depois de Said (1990) esse termo toma contornos negativos e é usado para a crítica da objetificação cultural operada pelo ocidente em não reconhecer as diferenças latentes entre as culturas orientais. É, sob a visão deste autor, um termo negativo que visa evidenciar relações de colonialismo existentes nas formulações teóricas ocidentais sobre as orientais. Apesar disso, as especificidades desse trabalho requererão o uso desse termo, e é meu dever explicar por que:

As noções, construções e vivências religiosas que encontramos aqui passam ao largo das religiões, se referem a elas, mas se apresentam como outra maneira de viver e operar a religiosidade. Uma maneira que têm diversas afinidades eletivas com o estilo Nova Era de

\footnotetext{
${ }^{9}$ Walter Franco. Respire Fundo. Rock Company: São Paulo, 1978. (Faixa 3)
} 
religiosidade, mas que guarda também algumas divergências. Uma delas seria, no caso dos compositores, uma certa hierarquização de uma teodicéia oriental frente aos outros símbolos religiosos trazidos ao processo de significação. Nas descrições sobre a religiosidade Nova Era consultadas para a elaboração desse trabalho (D'Andrea - 2000, Amaral - 1999, 2000), a vivência religiosa seria composta por momentos de troca comercial, obedecendo a lógica do mercado. Os entendimentos dos participantes então iam se constituindo como uma colcha de retalhos costuradas por eles. O que nos leva a uma outra diferença: a racionalização da crença por parte dos compositores. Embora D'Andrea (2000) encontre a reflexividade nos interstícios das vivências Nova Era, é sempre marcado pelo autor que isso acontece respeitando o plural, a prerrogativa de não haver julgamento (pois este seria uma característica do ego em contradição com o Self) e sempre se tomando a perspectiva do indivíduo. Já nos compositores estudados há quase que uma 'teologia' subtextual. Enquanto isso existe como movimento positivo (pelo menos no âmbito do julgamento, pelo que principalmente em Walter Franco há um não investimento na via intelectual de conhecimento, a busca e as formulações, no compositor se dão de maneira mais selvagem e processual) ${ }^{10}$, não há (ou há muito descontinuamente) um público que viva de fato aquilo que a música propõe, que construa suas crenças pelos termos e impulsos propostos ali. Ou seja, a religiosidade é algo que pertence aos compositores, mas uma vez nos dispositivos de reprodução pelos quais a música é distribuída, não é uma música consumida religiosamente. Embora, claro, sejam perceptíveis os elementos religiosos, e esses impulsos vão acabar por formar outros impulsos religiosos; mas de ordem e natureza diferente ao público Nova Era, que tem - e sabe que tem, além de buscar ter - experiências religiosas em suas vivências.

Temos então uma atuação religiosa fora do âmbito 'religião' que se aglutina em torno de algumas noções das ditas 'religiões orientais', e que se comporta de maneira sutilmente diferente às religiosidades Nova Era, embora haja muitas afinidades eletivas entre elas. Agora, falta dizer, que o conteúdo religioso não é algo que seja reproduzido como as religiões que pregam essas noções as elaboram, nem que esses influxos sigam qualquer tipo de raciocínio que exclua as outras leituras. Esse 'oriente' a que eles se referem é, em certa medida, inventado por eles. Sem dúvida a partir de leituras, palestras de gurus e quaisquer outros tipos de informação, mas não se refere a uma realidade tradicional de que eles sejam legatários.

E é aí que o termo 'orientalismo' traz algumas informações coincidentes com os movimentos que estudamos. Orientalistas, historicamente, eram aqueles que estudavam o

10 "Diga o que você quer dizer / diga t' na ponta da língua / o que você quer dizer // Só não diga dessa água / não beberei dessa água" canta Walter Franco no disco Tutano (Faixa 4, 2010) 
oriente no nascimento dos estudos sobre religião a formar uma idéia sobre o que era esse oriente enigmático e exótico (e sempre visto como uno) que se confrontava tanto à modernidade. A crítica de Said (1990) coloca esse oriente como algo inventado pelo ocidente a partir da prática do orientalismo, no sentido que um conjunto de civilizações com diferenças profundas entre si sejam entendidas a partir de poucas diferenças epistemológicas simplificadoras entre oriente/ocidente.

Ora, é a um oriente construído pelo ocidente na atividade desses compositores que estamos nos referindo. A diferença aqui é que esse oriente mais ou menos uno não é utilizado para dar uma dignidade especulativa a esses povos, nem a título de curiosidade étnica, e sim para construir, em torno dessa idéia redutora, uma religiosidade pós-tradicional - orientalista.

Vejo com bons olhos a apropriação cultural como circulação livre de idéias culturais, pois ela é a condição para a criatividade. Devemos ter em vista que não estou usando esse termo em seu sentido problemático, que é quando a população que cria bens culturais é desvinculada dela e marginalizada de sua própria criação. Aqui temos a apropriação cultural como antinomia da expressão meeting cultural (conhecimento dos contextos de certo produto cultural), superada pela prática da antropofagia nos meios artísticos desde 1922.

\section{2 - O Yoguin (do séc. XXI) como nova categoria ontológica para balizar a experiência pós-tradicional de vida em aprendizado}

Nessa reconstrução do oriente, um estado ontológico dos mais importantes em todas as tradições religiosas a que os compositores se referem é perdido absolutamente: o aprendizado direto com um mestre. Seja uma religiosidade com influências hindu, budista, zen, taoísta; nenhuma delas se sustenta sem grandes e profundas perdas sem o contato direto entre mestre e discípulo.

Esse discípulo, iniciado, é alguém a quem os ensinamentos serão passados de maneira integral e ele se tornará, no futuro, um mestre. Pela condição de discípulo, o aprendiz já é alguém com instrução privilegiada. Zimmer (2008, 50-52), delineia de maneira geral da condição de discípulo nas realidades tradicionais indianas, que depois também vai se reproduzir em suas estruturas monacais e que persiste nas estruturas tradicionais.

O discípulo que tem em suas entranhas a verdade anelada (...) submete-se sem reservas ao seu guru, prestando-lhe reverência como à encarnação do saber divino que lhe será ministrado, pois o mestre é porta-voz da sabedoria superior e possuidor de uma arte especial. (...) Deve compartilhar a moradia de seu mestre durante anos, servi-lo em sua casa e ajudá-lo no trabalho, seja seu ofício o de sacerdote, mago, 
asceta, médico ou oleiro. As técnicas necessitam ser aprendidas pela prática constante, enquanto a teoria é ensinada por meio da instrução oral, suplementada por um estudo completo dos manuais básicos. (...) O discípulo, como metal maleável, deve ser formado seguindo o molde do mestre que lhe serve de matriz, e isto não apenas em relação em questões de arte e saber, mas também a toda atitude pessoal. (ZIMMER, 2008: 50-51)

No ocidente, entretanto, manter essa estrutura se mostra como uma das muitas dificuldades enfrentadas pelas tradições. Peguemos o Budismo como exemplo. Nas sociedades budistas as pessoas que ensejam seguir a vida religiosa abandonam suas famílias e vão receber instrução formal em um mosteiro. Lá, dentre outras práticas, meditam incansavelmente. A estrutura monástica é mantida (financiada) pela comunidade budista leiga, que participa de festejos, orações e até mesmo alguns poucos retiros, mas de maneira geral a religiosidade é dada como no catolicismo brasileiro: se vai às festividades formais esporadicamente e segue-se a vida normalmente. A comunidade leiga não medita, pelo menos não rotineiramente, e não se espera que um leigo se ilumine.

No Brasil essa estrutura não se mantém. Se pegarmos também um exemplo pontual, o Budismo Tibetano liderado pelo Lama Padma Santem e centrado nas estruturas de CEBBs (Centros de Estudos Budistas Bodhisatva), vemos como duas classes religiosas, os leigos e os aprendizes, são fundidas. É claro que no Brasil o público do Budismo é bastante reduzido, embora seja uma religião que cresça bastante entre as elites sociais. O público disposto a praticar o budismo encontrado em cada grande cidade é bastante pequeno e, certamente, as pessoas dispostas a abandonar família e carreira são potencialmente diminutas, somando-se esse fato à falta de estrutura dessas instituições para manter monastérios. Aqui vemos que não há mais esses aprendizes exclusivos, enquanto a atividade leiga alcança maiores definições, com encontros para meditações, bem como estudos semanais e a participação sazonal em retiros onde são feitos os maiores exercícios de meditação e onde os ensinamentos mais sutis e secretos são ministrados, na medida em que ensinamentos sutis e secretos sejam todos, nesse caso específico, disponibilizados no You Tube ${ }^{11}$ para consulta em geral.

Enquanto há uma pequena minoria dos que integram essas estruturas que investem (como fez o Lama) em estudar com um mestre ou em um monastério na Índia, no Butão ou outro país, existe certa hierarquização dessa classe leiga-aprendiz. Há aqueles que podem ministrar práticas em Centros Budistas sem serem em si mestres, no sentido máximo que se dá, sendo apenas um leigo com mais estudo; e há aqueles que moram em comunidades

\footnotetext{
${ }^{11}$ Canal do Lama Padma Samten no You Tube: https://m.youtube.com/user/lamapadmasamten
} 
budistas, na qual constroem suas casas, constituem sua família, e de lá vão ao trabalho em seus carros próprios.

Vê-se aqui uma re-significação do discipulado e a fusão dos horizontes do leigo e do aprendiz. Pode-se perceber também um movimento parecido na atividade do Prof. Hermógenes, mas ele ainda vai além. Hermógenes é uma figura importante para esse trabalho, na medida em que um dos compositores estudados, BNegão, o cita no corpo da letra de suas canções e em falas nas entrevistas que concede à mídia inúmeras vezes, sempre se referindo a ele como uma fonte de sabedoria da qual bebe. Hermógenes é mestre de Hatha Yoga, a chamada Yoga Integral, e pela sua atividade social e seus escritos, ocupa um lugar de convergência entre tradição e o desenvolvimento de novas religiosidades. Ele também opera, ao constituir um grupo de seguidores, uma re-significação para a construção do papel a desempenhar pelos seus discípulos. Em uma linguagem que sempre reinstala termos sânscritos, que por vezes é criticada como simplificadora, ele instaura um panorama no qual o Yogi seria o mestre, aquele que detém o conhecimento e o estado espiritual elevado; em contradição o Yoguin seria o aprendiz, aquele que tomou a notável decisão de trabalhar em prol de sua evolução, tendo em vista a compaixão a todos os seres, mesmo sem se propor a abandonar esse mundo:

O sâdhana (método) do yoguin de séculos atrás fazia dele um anacoreta. O sâdhaka moderno fica entre seus irmãos de humanidade, mas mantendo-se isento, evitando mesmificar-se e corromper-se. Em seu ambiente - oficina, escola, escritório, repartição... - é ele um ponto de apoio aos outros quando sofrem e perdem o ânimo. (HERMÓGENES, 1975: 166)

Se fosse apenas isso poderíamos dizer que são confluentes a visão de discipulado encontradas nos escritos do Professor Hermógenes e praticadas pela estrutura Budista Bodhisatva comentada acima. Mas Hermógenes escreve dentro de um espírito de época onde se coloca como uma voz também direcionada àqueles que se encontram fora das tradições, porém que se entendem enquanto buscadores, diz ele:

O Yogui é aquele que já foi festivamente recebido pelo Pai na "comunhão dos santos", e, no acolhedor abraço da Graça do Pai, que morreu como um eu e ressuscitou como Deus.

Yoguin é aquele que, tendo despertado, visto a impermanência e falência dos valores mundanos, seja cristão, hinduísta, budista, judeu, maometano..., está a caminho, pagando o preço dos desafios, das fadigas, das quedas, de todos os sacrifícios, mas sempre avançando, sempre querendo chegar. (HERMÓGENES, 1975: 33) 
Ao compor essa idéia de Yoguin Professor Hermógenes relativiza qualquer tipo de estrutura social ou religiosa. Não importa, para ele, se a linguagem religiosa seja diferente da indiana que emprega, nem que o indivíduo opere fora ou em outra estrutura religiosa. Apesar das relatividades há algo que resta ao yoguin perceber, a "impermanência e falência dos valores mundanos".

Centrando na linguagem da citação acima, percebemos que Hermógenes usa termos conhecidos cristãos para aludir a uma concepção não cristã de "união com o todo em vida". Usa também quantas analogias forem possíveis com quaisquer outras religiões ao longo de seu texto. Para ele não importa o nome e os formatos das crenças ou como se organiza a estrutura, importa apenas uma coisa, a teodicéia, ou seja, a explicação do sofrimento, a descrição de como e por que os fenômenos acontecem e a receita soteriológica de uma busca generalizada para se "ressuscitar como Deus". De acordo com sua descrição, estamos todos alienados do fato de que somos nós, Deus, iludidos pelos valores mundanos que levam inconfundivelmente ao erro por tratar as pessoas como corpos separados de espíritos. $\mathrm{O}$ yoguin, na concepção de Hermógenes, então, é aquele que desperta para essa verdade e que busca meios de avançar no sentido de seu reencontro com o Deus que é, como parte pulverizada que remonta ao todo.

O livro dele a que nos referimos tem o título de: Yoga: caminho para Deus. Esta informação, quando já familiarizada com a ideia que ele compõe de yoguin como "aquele que caminha para Deus" leva a entender que este é mesmo um livro que investe na significação dessa nova maneira de aprender nesses tempos, um manual para yoguins do séc. XXI. Hermógenes matiza de diversas formas as características e pré-requisitos desse yoguin, buscando os conceitos hindus, mas sempre desprovendo-os de substancialidade cultural. Assim é necessário do yoguin visão correta perante à realidade (Viveka), desapego (Vairagya), anseio pela libertação dos seus condicionantes (Mumukshutva). E também, é necessário para Hermógenes que o yoguin guarde práticas:

Sâdhaka é o yoguin cumprindo seu papel no mundo, que é valorizar a oportunidade de existir, empregando, consciente e voluntariamente, o "talento" confiado, o dom da existência, para tornar-se Essência. E isto está a seu alcance, e é seu dever. O amado Jesus, Mestre incomparável, recomendou-nos, a todos nós - sâdhakas "sede perfeitos como o Pai do Céu é perfeito". (Hermógenes, 1975: 41)

Dessa maneira Hermógenes lança um alcance de uma teodicéia para o campo do possível dentro de diferentes religiões e de diferentes contextos sociais. O yoguin de 
Hermógenes se refere à religiosidade experimentada por fora das tradições ou apesar das tradições, propondo uma espécie de misticismo intra-mundano orientalista. Esse yoguin permaneceria um buscador, um aprendiz sem mestre, tendo sua individualidade como balizador das experiências e escolhendo livremente por quais caminhos percorrer.

Essa prática também teria seu rebatimento social, de maneira que ao se buscar reunirse a Deus o mundo iria ser povoado por seres conscientes e cheios de compaixão:

Quando cada indivíduo passar a defender os direitos dos outros como defende os seus e, ao mesmo tempo, se tornar fiel cumpridor de seu papel no mundo, isto é, seu dharma, a vida social vai melhor. Surgirá daí um mundo em harmonia, um mundo yoguin, um mundo cristão. (Hermógenes, 1975: 188)

Hermógenes propõe uma religiosidade para o mundo secular, uma religiosidade para além das religiões onde as únicas bases seriam a teodicéia que pode ser expressa de diversas formas somada à busca individual por aprendizado constante a partir de diversas fontes de conhecimento e sabedoria. Ao elaborar isso ele abre o caminho para que qualquer um se sinta um buscador a realizar a nobre promessa que faz de se reunir novamente com Deus ou Brahman. Essa concepção dialoga fortemente com a sensação daqueles que nutrem religiosidades pós-tradicionais de estarem em estados de aprendizado a partir de leituras e vivências, mas um aprendizado disperso e reunido pelo indivíduo que, a partir das considerações de Hermógenes passam a se imaginarem pertencentes a uma classe seleta de pessoas que buscam por libertação espiritual. Uma categoria de aprendiz um tanto quanto abstrata por não considerar o momento em que um yoguin passa a ser um yogui, ou melhor, uma maneira de entender um aprendiz como alguém que passa a vida a aprender sem nunca "chegar lá", nem nunca se tornar um mestre, senão por golpes do destino ou por intuição profética.

Essas elaborações do Professor Hermógenes são o que nos permitem o vislumbre de uma nova forma sutil de "sentir-se iniciado" que poderia ser operacionalizadas pelos compositores que são objeto desse estudo. Cujos exemplos de BNegão e Walter Franco provam que a experiência dessa vivência de ser aprendiz sem mestres ligados à uma teodicéia orientalista pode ser empregado na vivência religiosa pós-tradicional.

\section{3 - Conclusão}

Para potencializar e canalisar a busca por conhecimento religioso e sabedoria, BNegão e Walter Franco investem na criação de um sutil papel social de buscador e aprendiz, a que 
estamos chamando de yoguin do século XXI. Essa formulação pode ser utilizada como nova categoria ontológica para balizar a experiência de vida em aprendizado comum nas religiosidades pós-tradicionais, se mostrando muito útil para se analisar as essas religiosidades quando não são tão marcadas pelo consumo quanto aquelas pesquisadas por Leila Amaral $(1999,2000)$, bem como para entender outros artistas que investem a fundo na religiosidade orientalista e orientalizada.

A busca e o aprendizado aqui vão à direção holística e tem os seguintes elementos em comum: a) Tudo é um, a realidade é tomada como uma coisa só, assim não há separação individual entre os seres e não há nenhuma região do ser ou divindade que se coloque além ou aquém desse 'um'. b) Por causa dessa não-dualidade ninguém se vê livre das próprias ações e pensamentos, encontramos uma ideia de retorno da ação bem semelhante ao karma budista e hinduísta. c) Há tanto a ilusão quanto a energia negativa e maléfica impedindo a realização do ser, a pessoa então tem que lutar de forma sobre-humana contra essas energias que são identificadas como o egoísmo do indivíduo moderno e como o controle social do estado e do mercado. d) Isso torna a ação desse buscador extremamente política, uma política do desenvolvimento interior e da sensibilização e ensino das demais pessoas, descolado de um pensamento sobre a formulação de estratégias para o estabelecimento de um novo regime sócio-político como é o socialismo/comunismo clássico. e) Embora construído a partir de alicerces orientalistas esse movimento pode ser melhor descrito como orientalizado, uma vez que, muito além do que as figuras de linguagem podem mostrar, isso se insere mais na tradição da formulação de um anarquismo filosófico oriundo da ética da integralidade formulado historicamente por artistas como, por exemplo, Fernando Pessoa, Thoreau e Gary Snider. f) Essa religiosidade proposta pelos compositores ocupa um lugar que se situa entre a religião, a arte e a política.

Encontramos nesses compositores uma canção/filosofia ${ }^{12}$, uma canção que não é apenas a busca pelo belo e novo, mas acima de tudo que se propõe pensar a vida da comunidade e oferecer soluções para os problemas que ela enfrenta. Essa posição artística é diferente daquela estimulada pela indústria cultural, de forma que esses compositores vêm a sofrer fortes interdições pelo mercado (que deseja sempre arte alienante, e, como vimos acima, nada é mais radical do que a revolução permanente da forma, seja ela da ação social ou da arte). Isto redunda para eles em uma carreira de altos e baixos, havendo, em ambos os

\footnotetext{
${ }^{12}$ Não nos referimos à palavra filosofia como ela é tomada na disciplina história da filosofia, como pensamento metodológico. Mas como aquele pensamento que se demora nas questões essenciais de uma comunidade, e que, muito tranquilamente, pode cumprir seu dever sem método e sem institucionalização.
} 
casos, grandes hiatos entre um disco e outro. Por outro lado a mídia, para a valoração desses artistas, tenta colar neles a imagem de 'marginal' o que não é aceito, uma vez que eles pretendem oferecer soluções para a coletividade e não querem se apresentar como rebeldes, mas sim como radicais (no sentido dado por Marx), como intelectuais orgânicos.

Essa proposta é conseguida na medida em que as idéias desses compositores se transformam em ideias sociais, em ditos, em lições pichadas em muros. Assim eles fazem um trabalho de produção de ditos sociais e perspectivas de sentido cultural que auxilia quem queira a formular melhor sua ação no mundo e sua identidade. Isso não cria uma comunidade de yoguins, mas uma comunidade de ouvintes, que ao entrar em contato com aquele discurso leva aquelas informações em conta em sua visão de mundo. Além disso, podem instituir, mesmo que seja de forma difusa e não premeditada - ainda aqui uma influência orientalizante - uma corrente de artistas/aprendizes que tende a continuar a gerar atores sociais com matizes semelhantes.

Desta forma, a coletividade de materiais culturais orientalizados tem um papel ímpar na mudança de percepção, aquele movimento análogo (ainda que mais suavizado) ao da conversão das pessoas. Sendo uma força que empurra as pessoas a adotarem essa outra teodicéia e por vezes, até sendo o pivô da adoção de novas religiões e religiosidades pelo indivíduo. O maior exemplo disso é Monja Coen, mestre zen que sempre conta que começou a meditar por que os integrantes dos Beatles e do Pink Floyd meditavam, e ela nutrindo forte admiração por eles começou a adotar essa prática. O mesmo pode tender a acontecer com respeito a BNegão e Walter Franco, nas devidas proporções.

\section{Bibliografia}

AMARAL, Leila. Sincretismo em movimento: o estilo Nova Era de lidar com o Sagrado In: Maria Júlia Carozzi (org.). A Nova Era no Mercosul. Petrópolis: Vozes, 1999, pp.47-79.

Carnaval da Alma: comunidade, essência e sincretismo na Nova Era. Petrópolis: Vozes, 2000.

ANDRADE, Clodomir Barros de. A não dualidade do um (Bramãdvaita) e a não dualidade do zero (Súnyatãdvaya) na índia antiga. Tese de Doutoramento, Juiz de Fora, Programa de Pós-Graduação em Ciência da Religião PPCIR - UFJF, 2013.

BAUER, Martin w. GASKEL, George. Pesquisa qualitativa com texto imagem e som: Um manual prático. Petrópolis: Vozes, 2015.

BERGER, Peter. O dossel sagrado: elementos de uma sociologia da religião. São Paulo: Edições Paulinas, 1985.

. Perspectivas Sociológicas: Uma visão humanística. Petrópolis: Vozes, 1995. 
A dessecularização do Mundo: uma visão global. Religião e Sociedade, Rio de Janeiro, 21 (1): 9-24, 2000.

CALIL JÚNIOR, Alberto. "Entre o público e o privado: Sathya Sai Baba e o oriente no campo religioso brasileiro". Religião e Sociedade, 26/1, 2006, pp.05-22.

CAMPBELL, Colin. A orientalização do Ocidente: reflexões sobre uma nova teodicéia para um novo milênio. Religião e Sociedade, 18, n. 1, 1997. p. 5-22.

. A ética romântica e o espírito do consumismo moderno. Rio de Janeiro: Rocco,

2001

CAMPOS. Haroldo de. Uma poética da radicalidade. In. ANDRADE, Oswald. Pau Brasil. São Paulo, Editora Globo, 1990.

CAMURÇA, Marcelo Ayres. Espaços de hibridização, dessubstancialização da identidade religiosa e idéias fora do lugar. Ciencias Sociales y Religión/Ciências Sociais e Religião, Porto Alegre, ano 5, n. 5. 2003. p.37-65.

. Rede religiosa "new age" em Juiz de fora: espaço de "não lugares" e relativização de crenças. Minas das Devoções - Diversidade Religiosa em Juiz de Fora. Juiz de Fora: PPCIR - UFJF, 2003. p. 181-196

O conceito de Reencarnação no Espiritualismo moderno: Entre o Círculo de Sãmsara e o Evolucionismo Positivista. NUMEN: revista de estudos e pesquisa em religião. Juiz de Fora, v 3, no 1, Junho de 2003. p. 95-109

CAMURÇA, M. TAVARES, F. "Juventudes" e religião no Brasil: uma revisão bibliográfica. Numen: revista de estudos e pesquisa em religião. Juiz de Fora: v. 7, n. I. 2012. p. 11-46

CAPRA, Fritjof. O Ponto de Mutação. São Paulo: Cultrix, 1983.

- O Tao da Física - Uma análise dos paralelos entre a Física Moderna e o Misticismo Oriental. São Paulo: Cultrix, 2011.

CHENG, Anne. História do pensamento chinês. Petrópolis, RJ: Vozes, 2008.

D'ANDREA, Anthony. O self perfeito e a nova era: Individualismo e Reflexividade em religiosidades pós-tradicionais. São Paulo: Edições Loyola, 2000.

DUARTE, Joelma do Patrocinio. A contracultura e seus desdobramentos: Novas experimentações e religiosidade New Age. Tese de Doutoramento, Juiz de Fora, Programa de Pós-Graduação em Ciência da Religião PPCIR - UFJF, 2010.

HERMOGENES. Yoga: Caminho para Deus. Rio de Janeiro: Record, 1975.

I CHING: O livro das Mutações. Tradução e Comentários por Richard Wihelm. São Paulo: Pensamento, 2006.

JUNG, C.G. Wilhelm, R. O segredo da flor de ouro: um livro de vida chinês. Petrópolis: Vozes, 2013.

KEROUAC, Jack. Despertar: uma vida de Buda. Porto Alegre: L\&PM pocket, 2011. . Os vagabundos iluminados. Porto Alegre: L\&PM pocket, 2006.

LAO-TZU. Tao Te Ching. São Paulo: Martins Fontes, 2002.

MEIDER, Charles. The complete humouros sketches and tales of Mark Twain. New York: Double Day Company, 1961

MARIZ, Cecília Loreto. Secularização e dessecularização: comentários a um texto de Peter Berger. Religião e Sociedade, Rio de Janeiro, 21 (1): 25-39, 2000.

MALLARMÉ, Stéphane. Poemas. Tradução e notas críticas de José Lino Grunewald. Rio de Janeiro: Nova Fronteira, 2015.

MERTON, Thomas. A via de Chuang-Tzu. Petrópolis: Vozes, 1969.

. Místicos e Mestres Zen. Rio de Janeiro: Civilização Brasileira 1972.

. Zen e as Aves de Rapina. São Paulo: Cultrix, 1993. 
NOVAES, Regina. Juventude, religião e espaço público: exemplos "bons para pensar" tempos e sinais. Rio de Janeiro: Religião e Sociedade. 2012, vol.32, n.1, pp. 184-208. . Os jovens "sem religião": ventos secularizantes, "espírito de época" e novos sincretismos. Estud. Av. [on line]: 2004, vol. 18, n.52, PP. 321-330.

. Ouvir para crer: os Racionais e a fé na palavra. Religião e Sociedade, 20/1, 1990.

PEREZ, Léa Freitas. Algumas notas sobre religião e cultura de consumo. Horizonte. Belo Horizonte: abr./jun, 2010, v. 8, n. 17, p.146-155.

SAID, Edward W. Orientalismo: o oriente como invenção do ocidente. São Paulo: Companhia das Leras, 1990.

SANCHIS, Pierre. "O Campo Religioso Contemporâneo no Brasil". In: Ari Pedro Oro, Carlos Alberto Steil (Org). Globalização e Religião. Petrópolis: Vozes, 1997, p. 103-117.

STESSUK, S. O silêncio em espirais: Walter Franco. In: Anais do Congresso internacional da Associação Brasileira de Literatura Comparada (Abralic). São Paulo: 2008, v.11.

TAGG, Philip. Análise musical para "não-musos": a percepção popular como base para a compreensão de estruturas e significados musicais. In. Per Musi. Belo Horizonte, n.23, 2011, p. 7-18.

TATIT, Luiz. O Século da Canção. Cotia: Ateliê Editorial, 2004.

THORAU, Henry David. Desobediência Civil - Resistência ao Governo Civil / Walden. Rio de Janeiro: Ediouro (s/d.)

TOBIAS, Vinicius. Metal-Físico: Ensaio poético, crítico e fotográfico acerca do inatingível. Trabalho de Conclusão do Curso de Comunicação Social / UFSJ. São João del-Rei: 2013

. Os yoguins do séc. XXI: a representação do aprendiz orientalista pós-tradicional nas canções de BNegão e Walter Franco. Anais do CONACIR, Juiz de Fora, ano 1, vol. 1: 497504, 2015.

WISNIK, José Miguel. Sem receita. São Paulo: Publifolha, 2004.

. O som e o sentido: uma outra história das músicas. São Paulo: Companhia das Letras, 1989.

VARGAS, Herom. A canção experimental de Walter Franco. Comunicação \& Sociedade. Porto Alegre: jul./dez 2010, Ano 32, n. 54, p. 191-210.

WATTS, Alan. The Way of Zen. New York: Vintage, 1989.

ZIMMER, Heinrich. Filosofias da Índia. (Org. CAMPBELL, Joseph) São Paulo: Palas Athena, 2008. 